\title{
Depositional setting of the Late Archean Fe oxide- and sulfide-bearing chert and graphitic argillite in the Shaw Dome, Abitibi greenstone belt, Canada
}

\author{
Hiebert R.S. ${ }^{1,{ }^{*}}$, Bekker A. ${ }^{1,2}$, Houlé M.G. ${ }^{3}$, Rouxel Olivier ${ }^{4,5}$
}

${ }^{1}$ Department of Geological Sciences, University of Manitoba, Winnipeg, MB R3T 2N2, Canada

${ }^{2}$ Department of Earth Sciences, University of California, Riverside, CA, 92521, USA

${ }^{3}$ Geological Survey of Canada, Québec, QC G1K 9A9, Canada

${ }^{4}$ IFREMER, Centre de Brest, Unité Géosciences Marines, Plouzané, France

${ }^{5}$ Department of Oceanography, University of Hawaii at Manoa, HI 96822, USA

${ }^{*}$ Corresponding author : R. S. Hiebert, email address :

\begin{abstract}
:
Interbedded chert-rich exhalite and graphitic argillite are the only sedimentary rocks deposited in deepwater settings during long-lived hiatuses in mafic to ultramafic volcanism within the Hart area of the Shaw Dome in the Late Archean Abitibi greenstone belt in Canada. The Fe oxide- and sulfide-bearing, but predominantly cherty, exhalite lithological unit in the Hart area can be traced laterally to iron formation elsewhere in the Shaw Dome. Whole-rock as well as Fe and S isotope geochemistry suggest that the exhalite unit was formed as a result of direct precipitation from seawater, distally from hydrothermal centres. Fractionation of $\mathrm{Fe}$ isotopes through the precipitation of iron oxyhydroxides in a neutrally buoyant hydrothermal plume removed the heavier isotopes of $\mathrm{Fe}$, resulting in the negative $\delta 56 \mathrm{Fe}$ values observed in the exhalite in the Hart area. Archean seawater is generally considered to be anoxic, but moderate $\mathrm{Mn}$ enrichments (up to 1.87 weight\% $\mathrm{MnO}$ ) in exhalite along with negative $\mathrm{Fe}$ isotope values resulting from partial Fe(II) oxidation suggest the presence of oxygen in the upper part of the water column along the pathway of hydrothermal plumes from their source to the depositional site in the Abitibi greenstone belt. In contrast, the graphitic argillite contains abundant pyrite nodules and bands that exhibit systematic negative Fe isotope values, but does not show Mn enrichment. This unit likely formed in a zone of upwelling of nutrient-rich waters from deeper parts of the basin resulting in high organic productivity. Both exhalite and graphitic argillite have negative $\Delta 33 S$ values, suggesting that sulfur was derived from seawater sulfate, which is consistent with an anoxic atmosphere with sulfate aerosols produced by photochemical reactions. Combined, our data indicates disequilibrium between anoxic atmosphere and partially oxygenated upper part of the water column during periods of volcanic quiescence in the $\sim 2.7 \mathrm{Ga}$ Abitibi greenstone belt supporting the existence of oxidized oases within the Archean ocean.
\end{abstract}


It is widely accepted that the Archean atmosphere contained little or no oxygen (Farquhar et al.,

2011), with multiple S isotope data constraining the level of oxygen in the Archean atmosphere to less

37 than $10^{-5}$ PAL (e.g., Farquhar et al., 2000, 2001; Pavlov and Kasting, 2002). At the same time, multiple

studies using trace element and stable isotope data indicate the presence of low oxygen levels, locally or episodically in the Archean ocean (e.g., Anbar et al., 2007; Kaufman et al., 2007; Reinhard et al., 2009; Riding et al., 2014; Fralick and Riding, 2015), in highly productive areas of continental margins (e.g.,

Olson et al., 2013; Planavsky et al., 2014), or in continental settings in association with microbial mats (e.g., Lalonde and Konhauser, 2014). The current view of Archean surface redox conditions is that the anoxic atmosphere was in disequilibrium with locally and/or episodically oxidized continental and nearshore oceanic settings (e.g., Lyons et al., 2014). The extent of these oxidized oases, however, remains uncertain and is still debated (e.g., Lalonde and Konhauser, 2014).

47 Archean sedimentary rocks (Maynard, 2014). Mn enrichment occurs under most modern and formation, even though bacterially mediated, requires presence of at least low levels of oxygen. As such, sedimentary $\mathrm{Mn}$ deposits and $\mathrm{Mn}$ enrichments in sediments are rare in the Archean sedimentary record

51 (Maynard, 2014). As previously suggested (Rouxel et al., 2005; von Blanckenburg et al., 2008; Steinhoefel et al.,

53 2009; Tsikos et al., 2010; Planavsky et al., 2012; Busigny et al., 2014; Kurzweil et al., 2016), anoxygenic phototrophic oxidation could have established significant water column Fe concentration gradients and therefore Fe isotope trends - through ferric Fe removal during upwelling. However, several cases of 
et al., 2016; Mendes et al., 2016; Lantink et al., 2018), potentially indicating an extreme degree of Fe depletion in an expanding hydrothermal plume in association with precipitation of iron oxyhydroxides and, ultimately, Mn oxidation. Recently, Ossa Ossa et al. (2016) found Mn to be present in carbonates, orthosilicates, oxides, phyllosilicates, and pyrite in Mn-rich shales and BIFs of the Mesoarchean Mozaan

62 Group within the Pongola Supergroup in South Africa. However, it still remains unknown whether these rare occurrences of $\mathrm{Mn}$-enrichment reflect short-lived periods of atmospheric oxygenation or localized marine oxygen oases.

The Hart deposit within the Abitibi greenstone belt is a komatiite-associated Ni-Cu-(PGE) magmatic sulfide deposit that has derived much of the sulfur from the underlying metasedimentary rocks (Hiebert et al., 2016). The predominant sulfur source rock has been considered to be sulfur-rich iron formation (Houlé et al., 2010b), but locally it is significantly more silica-rich, and iron oxide-poor, than the typical iron formation leading to it being referred to as a lean iron formation. This unit also contains zones of significant sulfide accumulation as pyrrhotite- and pyrite-rich bands and lenses.

71 Although this unit is regionally interpreted as a true iron formation, the prevalence of silica-rich, and

72 iron oxide-poor, assemblage, as well as the abundance of sulfides in the vicinity of the Hart deposit

73 suggests that some environmental, depositional, or chemical conditions were different than elsewhere

74 along strike. Additionally, Bekker et al. (2010) argued that true iron formation should not contain

75 significant concentrations of sulfides, and that rocks previously classified as "sulfide-facies iron

76 formations" may be actually sulfide-rich shales or barren sulfide (e.g., lacking base-metal mineralization)

77 exhalative deposits formed from hydrothermal fluids either distally from the vent or under lowtemperature conditions. represent long-lived hiatuses in the rapid accumulation of volcanic rocks, during which siliciclastic and

81 chemical sedimentary rocks slowly accumulated (Thurston et al., 2008). These sedimentary rocks thus 
provide an insight into seawater composition and redox conditions as well as marine processes at the time of magmatic quiescence in the Archean ocean. In this study, we seek to constrain the depositional environment and diagenetic history of the exhalite and graphitic argillite lithologies within the Hart area of the Shaw Dome in the Abitibi greenstone belt through the comparison with two end-member processes. As iron formations are thought to be related to hydrothermal activity (Isley, 1995; Beukes and Gutzmer, 2008; Bekker et al., 2010), purely hydrothermal deposition of exhalative chert, iron oxides, and sulfides is considered as one end-member. The second end-member would be precipitation from ambient seawater directly unrelated to hydrothermal processes and may or may not be aided by biological activity (e.g., Li et al., 2015). We evaluate these two possible end-members using petrographic analysis of the sedimentary unit as well trace element and rare-earth element (REE) geochemistry to determine the chemical nature of the water column, along with multiple isotopes of sulfur and iron to determine the sources of these elements in the Fe-oxides and Fe-sulfides present in the sedimentary rocks. Additionally, we address the possibility that the chert exhalites and graphitic argillites were deposited during volcanic quiescence in the ca. 2.7 Ga Abitibi greenstone belt within a localized, marine oxidized oasis by studying geochemical proxies that constrain atmospheric and local marine redox conditions.

previously subdivided into 9 volcanic and sedimentary episodes, in which long-lived hiatuses in the rapid emplacement of volcanic rocks are represented by slowly accumulated sedimentary deposits (Thurston et al., 2008; Houlé and Lesher, 2011; Thurston et al., 2012). Conventionally, the Abitibi greenstone belt has been interpreted to have been developed autochthonously, with the volcanic sequences tectonically stacked upon each other, with only the younger Temiskaming and Porcupine sequences deposited in transtensional, pull-apart basins (e.g. Thurston and Chivers, 1990). Recently, however, it has been 
suggested that the volcanic rocks of the Abitibi greenstone belt were formed within a rift environment in which feeder dykes of the younger volcanic units crosscut older units, indicating autochtonous position (Ayer et al., 2002; Ayer et al., 2005; Ketchum et al., 2008; Thurston et al., 2008). Importantly, younger volcanic rocks contain zircon xenocrysts derived from older volcanic rocks suggesting that the volcanic sequences developed on top of each other (Ayer et al., 2002; Ayer et al., 2005; Thurston et al., 2008). In the Shaw Dome, the volcano-sedimentary succession is composed of the following units (Figure 1; Thurston et al., 2008; Houlé and Lesher, 2011; Thurston et al., 2012):

1) massive and pillowed, intermediate volcanic rocks and thin, but laterally extensive, iron formations of the 2734-2724 Ma volcanic sequence (Deloro);

2) felsic to intermediate, volcaniclastic rocks intercalated with komatiitic dikes, sills, lavas, and less extensive iron formations in the lower part of the 2710 - 2704 Ma volcanic sequence (lower Tisdale);

3) intercalated, tholeiitic, mafic, and komatiitic volcanic rocks of the middle part of the 2710 2704 Ma volcanic sequence (middle Tisdale); and

4) calc-alkaline, felsic to intermediate volcanic rocks in the upper part of the $2710-2704 \mathrm{Ma}$ volcanic sequence (upper Tisdale; Houlé et al., 2010a, b; Houlé and Lesher, 2011).

Felsic to intermediate, volcanic and sedimentary rocks of the lower Tisdale sequence, overlain by komatiitic and basaltic lava flows of the middle Tisdale sequence outcrop in the Hart area. At the base of the middle Tisdale volcanic package, komatiitic lava flows have thermomechanically eroded a wide (>200 m) channel into its footwall rocks, which are dominantly composed of felsic to intermediate, volcanic and volcaniclastic rocks with lesser amounts of chert, graphitic argillite, and minor iron formation of the regional lower Tisdale volcanic package (Figure 2; Houlé et al., 2010b). The chert and graphitic argillite appear to be interbedded on a meter-scale at and stratigraphically below the channel 
in drill cores. For simplicity, the prefix meta- will be omitted in the following description, but all rocks in the study area have been metamorphosed under lower to upper greenschist facies conditions (Thompson, 2005).

\section{Description of Sedimentary Lithologies in the Hart Area}

Regionally, the exhalite unit is generally continuous on the scale of several kilometers, and has been mapped and classified as iron formation, although in many locations it is described as a lean or chert-rich iron formation (Houlé et al., 2010b). However, based on the predominance of chert and silicarich lithologies in the vicinity of the Hart deposit, it has been reclassified as a distal exhalite by Hiebert et al. (2016; Figure 3a), since it is interpreted to have largely been formed through an exhalative process (cf. Ridler, 1971). The exhalite unit typically contains thin laminae of Fe-oxides or sulfides (Figures 3b, c; e.g., sample $\mathrm{H} 11-16-411.4 ; 86.2 \% \mathrm{SiO}_{2}, 10.9 \% \mathrm{Fe}_{2} \mathrm{O}_{3}$ ), but lacks any other sedimentary structures. Locally, the chert or silica-rich lithologies grade into typical banded iron formation (e.g., sample H1113C-387.2; $41.73 \% \mathrm{SiO}_{2}, 37.44 \% \mathrm{Fe}_{2} \mathrm{O}_{3}$ ) or massive sulfide composed of pyrrhotite and pyrite, but these sulfidic lithologies are thought to extend for only a few tens of meters, and cannot be traced between drill holes and outcrops. The sulfides within the exhalite typically contain fine-grained pyrrhotite (0.1 $0.2 \mathrm{~mm}$ in size) that appears to have been locally replaced by pyrite $(0.25-0.6 \mathrm{~mm}$ in size), which still contains inclusions of pyrrhotite (Figure 3d). The sulfides form lenses or are found to be replacing Feoxide laminae. The unit also contains minor silicates, such as actinolite and chlorite as replacement minerals, and calcite as a replacement mineral and, possibly, as cement.

The graphitic argillite is only observed in the drill core in the eastern part of the Hart property. Based on visual estimates with optical microscope and geochemical data, it is composed of $35-50 \%$ graphite by volume (TOC content is up to $17.6 \mathrm{wt} . \%$ with the average of $8.5 \mathrm{wt} . \%$ ) and $10-40 \%$ sulfide by volume (TS content is up to $47.4 \mathrm{wt} . \%$ with the average of $28.0 \mathrm{wt} . \%)$, with variable amounts of metamorphic chlorite, epidote, actinolite, and quartz (10-60 wt.\% $\mathrm{SiO}_{2}$; Figures $\left.4 \mathrm{a}, \mathrm{b}\right)$. Sulfide in the 
153

154

155

156

157

158

159

160

161

162

163

164

165

166

167

168

169

170

171

172

173

graphitic argillite takes two forms, large (1-1.5 cm in diameter) pyrite nodules and bands (Figure 4c), or finely disseminated pyrite ( $<0.1 \mathrm{~mm}$ in diameter; Figure $4 \mathrm{~d})$.

\section{Multiple S and Fe Isotope Background}

The majority of earlier research attempted to characterize the processes producing the sulfides

in sedimentary rocks using $\delta^{34} S$ values, but the range of sulfur isotope values recorded in Archean

supracrustal rocks is much smaller than that in Phanerozoic examples, commonly resulting in near-to-

mantle $\delta^{34} S$ values (Ripley, 1999). This can lead to a difficulty in identifying the processes responsible for the origin of these sedimentary sulfides. The values of $\delta^{34} S$ are expressed in parts per thousand (\%o or per mil), and are defined as:

$$
\delta^{34} S=1000 *\left(\frac{\frac{{ }^{34} S}{{ }^{32} S} \text { sample }}{\frac{{ }^{34} S}{{ }^{32} S} V-C D T}-1\right)
$$

where V-CDT is a reference scale defined by the isotopic composition of IAEA-S-1, a sulfur reference material distributed by the International Atomic Energy Agency (IAEA, Vienna), and calibrated to have $\delta^{34} \mathrm{~S}_{\text {IAEA-S-1 }} \equiv-0.3 \%$ based on the historical Canõn Diablo Troilite reference material (Coplen and Krouse, 1998). A similar formula is used to calculate $\delta^{56} \mathrm{Fe}$, with masses 56 and 54 forming the ratio and IRMM14 used as the reference standard (see recent review by Dauphas et al., 2017).

Under oxygenated Earth's surface conditions, sulfur isotope fractionation is controlled strictly by relative isotope mass differences and, therefore, is a completely mass-dependent process. However, as a result of photochemical reactions in the Archean anoxic atmosphere, atmospherically processed Archean sulfur exhibits widespread mass-independent fractionation that can be characterized by the difference between the $\delta^{33} \mathrm{~S}$ value expected from normal mass-dependent fractionation and the measured $\delta^{33} S$ value (Farquhar and Wing, 2003). It can be calculated using measured $\delta^{33} S$ and $\delta^{34} S$ values (in per mil) as: 


$$
\Delta^{33} S=\delta^{33} S-\left[\left(\frac{\delta^{34} S}{1000}+1\right)^{\lambda_{R F L}}-1\right] \times 1000
$$

175

176

178

179

where the $\lambda_{\mathrm{RFL}}$ has been defined as the slope of the reference fractionation line for ${ }^{33} \mathrm{~S}$ and ${ }^{34} \mathrm{~S}$ isotopes equal to 0.515 .

Photochemically fractionated sulfur can then be delivered to seawater and ultimately sediments. Two isotopically distinct sulfur pools were formed by the photochemical reactions in the Archean atmosphere: 1 ) a reduced pool with positive $\Delta^{33} S$ and $\delta^{34} S$ values, and 2) an oxidized pool with negative $\Delta^{33} S$ and $\delta^{34} S$ values (e.g., Farquhar et al., 2002; Ono et al., 2003; Figure 5). The reduced pool is inferred to have been delivered to the Archean ocean as either elemental sulfur $\left(S^{0}\right)$ aerosols or sulfide $\left(\mathrm{S}^{2-}\right)$, which then reacted with $\mathrm{Fe}^{2+}$ dissolved in the anoxic seawater and precipitated as disseminated Fesulfide in sediments (Ono et al., 2009; Maynard et al., 2013; Marin-Carbonne et al., 2014). The oxidized sulfur pool, delivered from the atmosphere as sulfate aerosols, is thought to have been either reduced by bacterial metabolism and incorporated into paleosols on the continents (Maynard et al., 2013), or added to seawater as dissolved sulfate (Farquhar et al., 2002). Once delivered to seawater, sulfate was either reduced via bacterial sulfate-reducing metabolism to form eventually pyrite nodules in organic matter-rich sediments during diagenesis, or cycled through submarine hydrothermal systems. Under hydrothermal conditions, seawater sulfate is first precipitated as Ca-sulfate (anhydrite), with a remaining fraction becoming eventually reduced at high temperature and vented at the seafloor as $\mathrm{H}_{2} \mathrm{~S}$ rich hydrothermal fluids forming barren massive sulfide lenses distally and base-metal volcanogenic massive sulfide deposits proximally to hydrothermal centers (e.g., Bekker et al. 2009; Jamieson et al., 2013). A significant fraction of anhydrite is redissolved as aging and cooling oceanic crust is transported away from spreading mid-ocean ridges (Alt, 1995).

Once in aqueous phase either on the land or in the ocean, the near-to-zero to negative $\delta^{34} \mathrm{~S}$ values of $\mathrm{SO}_{2}$-derived sulfate could have been further modified by mass-dependent processes; for example, by bacterial or thermochemical seawater sulfate reduction, resulting in nodules or layers of 
198

199

200

201

202

203

204

205

206

207

208

209

210

211

212

213

214

215

216

217

218

219

220

221

sulfides in sediments with variable $\delta^{34} S$ values, but with consistently negative $\Delta^{33} S$ values (Ono et al., 2003, 2009; Bekker et al., 2009; Marin-Carbonne et al., 2014). Unlike in modern oceans, however, Archean seawater had relatively high iron content, but low sulfate concentrations, less than 80-200 $\mu \mathrm{mol} \mathrm{L}{ }^{-1}$ (Habicht et al., 2002; Jamieson et al., 2013), which resulted in small sulfur isotopic fractionations during bacterial sulfate reduction in a closed to semi-closed pore-water system due to much faster sulfate reduction with respect to sulfur transport rates (Brunner and Bernasconi, 2005; Detmers et al., 2001). As a result of nearly complete reduction of seawater sulfate in anoxic, organic matter-rich sediments, Archean pyrite does not exhibit the large variations in $\delta^{34} S$ values seen in modern marine sediments.

Iron isotope fractionation is thought to be dominantly controlled by redox reactions. Igneous rocks typically have $\delta^{56} \mathrm{Fe}$ values of $\sim 0.1 \%$ (e.g., Beard et al., 2003 ; see also recent review by Dauphas et al., 2017), but redox reactions under surface conditions, as recorded by sedimentary rocks with significant authigenic Fe enrichment (e.g., iron formations and black shales), tend to fractionate Fe in oxidized Fe-mineral species towards positive $\delta^{56} \mathrm{Fe}$ values (e.g., Planavsky et al., 2012), and in reduced Fe-mineral species towards negative $\delta^{56} \mathrm{Fe}$ values (e.g., Rouxel et al., 2005). During oxidative precipitation from fluids containing dissolved $\mathrm{Fe}^{2+}$, redox reactions will preferentially remove the heavier isotopes of Fe with oxidized phases resulting in residual iron in the fluid having a lower $\delta^{56} \mathrm{Fe}$ value. For example, precipitation of magnetite corresponds to a fractionation factor $\Delta^{56} \mathrm{Fe}_{\mathrm{Fe}(I) \text { aq-magnetite }}{ }^{\sim-1.3 \% \text { o }}$

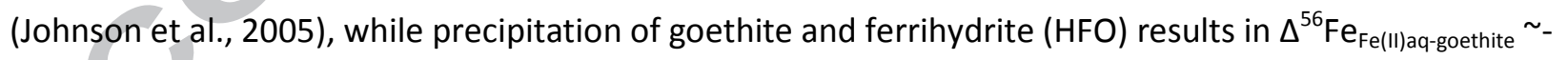
1\%o (Beard et al., 2010) and $\Delta^{56} \mathrm{Fe}_{\mathrm{Fe}(I I) a q-H F O} \sim-3.2 \%$, respectively (Wu et al., 2011). The "reservoir" effects during partial $\mathrm{Fe}^{2+}$ oxidation have been well demonstrated in biotic and abiotic experimental studies (e.g., Balci et al., 2006; Croal et al., 2004) and in modern redox-stratified aqueous environments (Busigny et al., 2014; Rouxel et al., 2008, 2017). Dissimilatory $\mathrm{Fe}^{3+}$ reduction (DIR), which is known to produce isotopically light Fe in diagenetic environments (Crosby et al., 2007; Tangalos et al., 2010; Percak- 
222 Dennett et al., 2011), may also produce a $\mathrm{Fe}^{2+}$ pool with negative $\delta^{56} \mathrm{Fe}$ values. A clear distinction

223 between these two mechanisms (i.e., partial $\mathrm{Fe}^{2+}$ oxidation versus partial $\mathrm{Fe}^{2+}$ reduction) as the source of

224 isotopically light $\mathrm{Fe}^{2+}$ has been generally difficult to draw, even in modern marine or diagenetic

225 environments (Severmann et al., 2008; Chever et al., 2015). Both low and high-temperature alteration of

226 oceanic crust by seawater leads to the preferential release of more soluble $\mathrm{Fe}^{2+}$, resulting in seafloor

227 hydrothermal fluids having $\delta^{56} \mathrm{Fe} \leq 0 \%$ (Rouxel et al., 2003; Rouxel et al., 2008). As pyrite is often

228 precipitated through a mackinawite $\left(\mathrm{FeS}_{0.9}\right)$ precursor, it preferentially incorporates the lighter isotopes

229 of Fe, resulting in $\delta^{56} \mathrm{Fe}$ values of the sulfide to be 0.3 to $0.9 \%$ o lower than residual dissolved $\mathrm{Fe}^{2+}$ (Butler

230 et al., 2005; Guilbaud et al., 2011). Further (i.e., partial) conversion to pyrite might also result in

231 additional fractionation, resulting in final values of $\delta^{56} \mathrm{Fe}$ that are 1.7 to $3.0 \%$ lower than the initial

232 dissolved $\mathrm{Fe}^{2+}$. Therefore, Fe delivered to the oceans by hydrothermal fluids, and any Fe-sulfides

233 precipitated from these fluids, typically have slightly negative $\delta^{56} \mathrm{Fe}$ values, although heavier values of

234 the hydrothermal Fe flux are expected in the case of extensive Fe-sulfide precipitation in hydrothermal

235 plume environments (Bennett et al., 2009; Rouxel et al., 2016; Lough et al., 2017). There are several

236 notable exceptions of Fe-oxide iron formations of Archean and Paleoproterozoic age with negative Fe

237 isotope values that are typically $\mathrm{Mn}$-enriched and largely deposited in shallow-water settings (e.g.,

238 Rouxel et al., 2005; Tsikos et al., 2010; Planavsky et al., 2012; Haugaard et al., 2016; Mendes et al., 2016;

239 Lantink et al., 2018). Their iron isotope values are considered to be the result of reservoir effects (e.g.

240 Rayleigh distillation) associated with the earlier removal of Fe-oxides and oxyhydroxides resulting in

241 negative $\delta^{56} \mathrm{Fe}$ values of the residual $\mathrm{Fe}$ in the spreading hydrothermal plume distally from the

242 hydrothermal vents (Planavsky et al., 2012). 
All samples $(n=27)$ for this project were selected from drill cores and surface trenches produced by Northern Sun Mining Corp. (Table 1). Sampling of drill cores and surface trenches was conducted to obtain a wide range of lithologies from the exhalite and graphitic argillite units. heating to create a glass bead, which was analyzed by X-ray fluorescence (XRF), and trace, including rare-earth, elements were measured on an inductively coupled plasma-mass spectrometer (ICP-MS)

257 after digestion in a closed vessel using multi-acid technique. At Acme Labs, samples were prepared via a 258 lithium borate fusion and were analyzed for major elements by ICP-ES, and for trace elements by ICPMS. In both labs, total C and S were determined by oxidation through combustion of the sample in an oxygen-rich environment and detection of $\mathrm{CO}_{2}$ and $\mathrm{SO}_{2}$ by infrared absorption (LECO elemental analyzer). Both labs use duplicate analyses of samples and certified reference materials to confirm the precision and accuracy of data.

Bulk Rock S Isotope Analysis analyzed at the Stable Isotope Laboratory of the Department of Earth and Planetary Sciences, McGill 
266

267

268

269

270

271

272

273

274

275

276

277

278

279

280

281

282

283

284

285

286

287

288

University. The sulfur isotope compositions are reported on the V-CDT scale, and the $\Delta^{33} \mathrm{~S}$ value of reference material IAEA-S-1 is taken to be $0.094 \%$ based on repeated analysis of the standard at this facility. Repeat analyses throughout the entire analytical procedure returned $2 \sigma$ uncertainties on $\delta^{34} S$ and $\Delta^{33} S$ values that are $<0.25$ and $<0.01 \%$, respectively.

\section{Fe Isotope Analysis}

Aliquots of sample powders were dissolved for Fe isotope analysis using the same method as described in Rouxel et al. (2005) and Hiebert et al. (2015) at the Pôle Spectrométrie Océan, IFREMER (Brest, France). Internal precision of data was determined through duplicate analysis of internal reference standards IF-G (iron formation), BHVO-1 (Hawaiian Island basalt), and DTS-1 (Cr-rich ultramafic rock), and the long-term external reproducibility is $0.08 \%$ for $\delta^{56} \mathrm{Fe}$ values $(2 \sigma)$. Fe isotope values are reported relative to the standard IRMM-14, using the conventional delta notation (Table 1).

\section{Microbeam Analysis}

Two samples were selected for analysis on a Cameca SX100 electron microprobe at the University of Manitoba. These samples (H11-13C-387.2 and H11-08-63.9) were analyzed using energy dispersive $\mathrm{x}$-ray spectroscopy (EDS) to determine the mineral(s) that host $\mathrm{Mn}$ in exhalite.

\section{Results}

\section{Major and Trace Element Geochemistry}

Major element variations generally reflect the lithology and dominant mineralogy, with chertrich and iron oxide-rich varieties having high $\mathrm{SiO}_{2}$ and $\mathrm{Fe}_{2} \mathrm{O}_{3}$ contents (Table 1). Some samples have compositions controlled by the abundance of pyrrhotite and pyrite, with high $\mathrm{Fe}_{2} \mathrm{O}_{3}$ and $\mathrm{SO}_{2}$, but low $\mathrm{SiO}_{2}$. In general, low concentrations of $\mathrm{TiO}_{2}$ and $\mathrm{Al}_{2} \mathrm{O}_{3}$ are found in all samples of exhalite, with the exception of high $\mathrm{Al}_{2} \mathrm{O}_{3}$ (17.01 wt.\%) found in a sample of silicate-rich iron formation with high sulfide content. Notably, all exhalite samples are enriched in $\mathrm{MnO}$ above the crustal levels of $~ 0.1$ wt. \% 
(Rudnick and Gao, 2014) with values as high as 1.87 wt.\%. Graphitic argillite samples have extremely variable compositions depending on the abundance of graphite, pyrite, and silicate minerals. chemical sediments, including cherts and iron formations, have been used to describe the composition and redox state of the ancient water column in recent publications (e.g., Bolhar et al., 2004; Barrie, 2005; Kato et al., 2006; Frei et al., 2008; Bekker et al., 2013; Planavsky et al., 2010; Thurston et al., 2012). Graphitic argillite samples from the Hart area typically have low, but variable, Zn concentration, with the range of values from 3 to $734 \mathrm{ppm}$. Mo concentrations of 0.3 to $10.9 \mathrm{ppm}$ are also comparable to data for shales of similar age (Scott et al., 2008). Importantly, almost all samples have Mo Gao, 2014). In addition, concentrations of $U$ are also very low compared to crustal average: 0.03 to 0.77 $\mathrm{ppm}$ (with the average of $0.22 \mathrm{ppm}$ ) for exhalite, and 0.36 to $0.59 \mathrm{ppm}$ (with the average of $0.47 \mathrm{ppm}$ ) for graphitic argillite, which is below various estimates for average crustal levels of 1.5 to $2.8 \mathrm{ppm}$ (see Rudnick and Gao, 2014).

The abundances of rare earth elements have been normalized to the Post-Archean average Australian Shale (PAAS) as it is the most commonly used reference for normalizing similar lithologies, allowing for easy comparison to previous work (Figure 6; refer to Table 3 for data and formulas used to calculate anomalies). The exhalite has generally positive anomalies for Eu and $Y$ (Figure 6b). A significant positive Eu anomaly (Eu/Eu*; see Table 3 for method of calculation of REE anomalies), ranging from 1.2 to 8.1 , is found in all exhalite samples. Exhalite samples have a wide range of Ce anomalies, both positive and negative, with values ranging from 0.41 to 1.30 , with positive Ce anomalies not created as an artifact of a positive La anomaly influencing the calculation (Figure 6a; Table 3). Values for Y/Ho ratio

311 have a wide range from 32.6 to 70.0 , but are generally superchondritic, similar to those found in 312 seawater (Bolhar et al., 2004). The rare earth element (REE) patterns also show a general heavy-REE 
(HREE; Figure $6 \mathrm{~b}$ ) enrichment as indicated by normalized $\mathrm{Pr} / \mathrm{Yb}$ and $\mathrm{Gd} / \mathrm{Yb}$ ratios ranging from 0.12 to

0.99 and 0.51 to 1.76 , respectively, similar to modern hydrogenous chemical sediments (Table 1 ; Bau, 315 1999).

The graphitic argillites lack significant anomalies for $\mathrm{Ce}$ and $\mathrm{Y}$, but have positive Eu anomalies

317 (1.28 to 2.55; see Figure 7). Values for $\mathrm{Y} / \mathrm{Ho}$ have a narrow range from 27.3 to 29.0 and are lower than those for modern seawater and close to those of chondrites ( 26), indicating limited uptake of REE from seawater. The rare earth element (REE) data for graphitic argillites also shows a predominantly flat pattern (Figure 7b), with only weak HREE enrichment as shown by normalized $\mathrm{Pr} / \mathrm{Yb}$ and $\mathrm{Gd} / \mathrm{Yb}$ values ranging from 0.92 to 1.09 and 0.61 to 0.78 , respectively (Table 3 ).

Petrography and Scanning Electron Microscopy (SEM)

High Mn concentrations within the exhalite unit were further investigated to determine the

324 mineral host of $\mathrm{Mn}$. The EDS analyses of exhalite samples found that $\mathrm{Mn}$ was hosted predominantly in

325 carbonates, chlorite, and actinolite (Figure 8). No significant Mn enrichment was observed in sulfides

326 and oxides. The presence of $\mathrm{Mn}$ in carbonates and metamorphic silicates, without significant

327 enrichments in sulfides and oxides, suggests that Mn was not likely to have been hosted in the

328 oxyhydroxides during early diagenesis, but may have been adsorbed to the surface of clay minerals and

329 later incorporated into diagenetic carbonates.

\section{Stable Isotopes}

Sulfur isotope data have been used as a tracer of biological activity in modern and ancient aqueous environments, and, in the case of Archean rocks, also contain a record of atmospheric reactions (e.g., Farquhar et al., 2000; Ono et al., 2003, 2009). On a plot of $\delta^{34} S$ against $\delta^{33} S$ values for sediments from the Hart area, the data forms a trend offset from, but generally parallel to the terrestrial fractionation line (TFL) that follows mass-dependent fractionation (Figure 9a). The offset from the TFL is 
due to non-mass dependent fractionation in the Archean atmosphere (Farquhar et al., 2000), and the magnitude and consistency of this offset is expressed on a plot of $\delta^{34} S$ against $\Delta^{33} \mathrm{~S}$, where values along the TFL would plot with $\Delta^{33} S=0 \%$ (Figure 9b).

Exhalite samples have a large range of $\delta^{34} S$ values, -11.4 to $+7.6 \%$ o $(n=24)$, and an average value of $-2.1 \%$ (Figure $8 \mathrm{~b}$; Table 2). The $\Delta^{33} \mathrm{~S}$ values have a much smaller, and consistently negative, range from -1.37 to $-0.34 \%$, with an average value of $-0.62 \%$.

343 with the range of +1.6 to $+5.0 \%$ o $(n=3)$. This positive range, although overlapping with that of the exhalite, has a positive average value of $+3.4 \%$, significantly different from that of the exhalite. The $\Delta^{33} \mathrm{~S}$ values of the graphitic argillite have a small, and consistently negative, range, similar to that of the exhalite, -0.94 to $-0.19 \%$, with an average value of $-0.47 \%$ (Figure $9 b$ ). This suggests that sulfur in

347 sulfides in the graphitic argillite was likely derived from the same sulfate source as the exhalite sulfides. argillite exhibits a range of -1.96 to $-1.66 \%$ o $(n=3)$, with an average value of $-1.82 \%$ (Figure 10$)$.

Considering that co-existing Fe-bearing minerals in such samples may have distinctly different $\delta^{56} \mathrm{Fe}$

352 values, it is important to relate bulk-rock $\delta^{56} \mathrm{Fe}$ signature and mineralogy. For example, the various 353 proportions of isotopically light pyrite (or isotopically heavy Fe-oxides) and lithogenic components with $354 \delta^{56} \mathrm{Fe}=0.09 \%$ may produce a significant range in bulk $\delta^{56} \mathrm{Fe}$ values (e.g., Duan et al., 2010; Severmann 355 et al., 2008; Rouxel et al. 2016). As shown in Figure 11, there is no significant correlation between $\delta^{56} \mathrm{Fe}$ 356 values and $\mathrm{S}$ concentration, suggesting that variations in $\delta^{56} \mathrm{Fe}$ are not a result of mixing between 357 isotopically light pyrite and lithogenic components. 


\section{Discussion}

\section{Environmental Implications of Major and Trace Element Data}

Generally low $\mathrm{TiO}_{2}$ and $\mathrm{Al}_{2} \mathrm{O}_{3}$ concentrations in the exhalite unit indicate low detrital input (cf.

Slack et al., 2007), and, when plotted against each other (Figure 12a), show no apparent trend. Similarly,

$\mathrm{Zr}$ versus $\mathrm{TiO}_{2}$ plot shows no apparent trend (Figure 12b). The trends found within the graphitic argillite

data, however, show the expected pattern for detrital contribution to sediments (Figures 12a and b; cf.

Pecoits et al., 2009). When recalculated to elemental weight percent, ratios of $\mathrm{Fe} / \mathrm{Ti}$ and $\mathrm{Al} /(\mathrm{Al}+\mathrm{Fe}+\mathrm{Mn})$

can be used to show a continuum between the exhalite and graphitic argillite units, suggesting

Bonatti et al., 1972; Böstrom et al., 1969; Böstrom, 1973; Pecoits et al., 2009).

The trace element concentrations and ratios, and rare-earth element anomalies in the Hart area

Hart area, and the ratio of $\mathrm{Zn}(\mathrm{ppm}) / \mathrm{Al}_{2} \mathrm{O}_{3}$ (wt.\%) fall within the range of values compiled by Scott et al.

(2008, 2013) for organic-rich shales deposited in the anoxic Archean oceans.

Partin et al. (2013a, b) evaluated $U$ concentrations and authigenic $U$ enrichment $\left(U_{\text {auth }}=U-T h / 3\right)$

377 in the Archean, prior to the rise of atmospheric oxygen, for both iron formations and black shales. In the

378 Archean iron formations, before the rise of atmospheric oxygen between ca. 2.45 and 2.32 Ga (e.g.,

Bekker et al., 2004; Gumsley et al., 2017), very low U concentrations and $U_{\text {auth }}$ enrichments were found

380 (Partin et al., 2013a), and in the Hart exhalites $U$ concentrations are comparable to the typical values

381 found in the similar Archean deposits (Barrie, 2005; Partin et al., 2013a). In the Archean black shales, 
Partin et al. (2013b) found average $U$ concentration and $U_{\text {auth }}$ enrichment of $3.8 \mathrm{ppm}$ and $0.9 \mathrm{ppm}$,

respectively. Graphitic argillites from the Hart area have $U$ concentrations well below the average value for the Archean shale (Partin et al., 2013b). Low, pre-GOE (Great Oxidation Event) levels are also observed in our samples for other trace elements such as Co (cf. Swanner et al., 2014), and Cr (cf. Konhauser et al., 2011). Combined, this trace element dataset suggests deposition under a generally anoxic water column, although the rapid precipitation of Fe in modern hydrothermal settings (e.g., in distal part of hydrothermal plume where seafloor microbial mats grow) would be also consistent with such signatures (Rouxel et al., 2016, 2017). However, Mn concentrations in exhalite samples are anomalously high for anoxic environments. The possible link between $\mathrm{Mn}$ enrichment and localized oxygenated oases in the Archean ocean, proposed in previous studies (cf. Olson et al., 2013; Ossa Ossa et al., 2016; Planavsky et al., 2014), is discussed in more detail below.

Positive La, Gd, and $\mathrm{Y}$ anomalies have been observed in the modern seawater and have been explained by REE complexation on particle surfaces (e.g., Bolhar et al., 2004). The positive Eu anomalies are common in Archean sediments, and have been interpreted to represent strong influence of hightemperature, hydrothermal, anoxic fluids on seawater composition during that time (e.g., Bau and Dulski, 1996; Bolhar et al., 2004; Slack et al., 2007; Bekker et al., 2010, 2014; Planavsky et al., 2010). By analogy, positive Eu anomalies of the Hart area exhalite indicate influence of hydrothermal fluids on seawater composition at the depositional site and, potentially, relative proximity to high-temperature hydrothermal vents. The rare-earth element (REE) patterns of the Hart area exhalites also show a

401 general heavy-REE (HREE; Figure 6b) enrichment as indicated by normalized $\mathrm{Pr} / \mathrm{Yb}$ and Gd/Yb values 402 ranging from 0.27 to 0.99 and 0.51 to 1.76, respectively (Table 3). These $\mathrm{Pr} / \mathrm{Yb}$ values overlap with 403 higher values within the range reported for Abitibi BIFs by Thurston et al. (2012), which were interpreted to characterize BIFs formed in shallower water than those with lower $\mathrm{Pr} / \mathrm{Yb}$ ratios (Kamber, 
2010; Thurston et al., 2012). Combined, these REE characteristics of the Hart area exhalites record seawater composition dominated by high-temperature hydrothermal flux.

In modern environments, negative Ce anomalies are generated under oxidizing conditions in river waters and seawater, but are dominantly produced by Ce scavenging onto Fe-Mn nodules and crusts in deep, oxygenated ocean waters (Bau and Dulski, 1996; Bau, 1999; Slack et al., 2007). As the deep seawater was unlikely to have been oxygenated during the Archean, fractionation may have occurred locally in environments where REE were scavenged by Fe-Mn particles. The presence of small, true positive and negative Ce anomalies in the exhalite samples could suggest redox cycling of REE coupled to formation and dissolution of Fe-Mn oxyhydroxides. Following the model of German et al. (1991) and Slack et al. (2007), Fe-Mn-rich particles generated in local, shallow oxidized environments (and producing negative Ce anomalies in the upper part of the water column) would have been dissolved below the redoxcline in deeper waters, returning the Ce back to the seawater and erasing any negative Ce anomaly, or even producing a positive Ce anomaly. Whether a similar mechanism could operate in hydrothermal plume-influenced environments remains, however, poorly constrained.

The near-chondritic values of $\mathrm{Y} / \mathrm{Ho}$ for the graphitic argillite are lower than those for the modern seawater and the Hart area exhalites, suggesting that their REE composition is dominated by a detrital signal. Positive Eu anomalies however suggest that significant hydrothermal flux continued during deposition of the graphitic argillite.

\section{Formation of the Graphitic Argillite Unit}

The negative $\delta^{56} \mathrm{Fe}$ values in the graphitic argillite unit are surprising considering the high abundance of detrital/lithogenic material. As mentioned above, the lack of correlation between $\mathrm{S}$ and $\delta^{56} \mathrm{Fe}$ values suggests that the range of $\delta^{56} \mathrm{Fe}$ values is not solely explained by the contribution of isotopically light Fe-sulfides (i.e., mixing between lithogenic and sulfide components). This likely implies that the Fe incorporated into sulfides and other authigenic (including silicate minerals) phases was 
derived from water masses with isotopically light Fe as is also envisioned for the exhalite deposits except that there was stronger influence of hydrothermal plumes on water masses from which Feoxyhydroxides precipitated to form the exhalite. The abundance of carbon in graphitic argillite unit suggests deposition in an area of high organic productivity, possibly in a zone of upwelling from deeper part of the ocean basin. Low P concentrations, which are lower than expected for modern sediments deposited in areas of high biological productivity, are common to Archean organic matter-rich shales amounts of P from deep oceans (Bjerrum and Canfield, 2002).

The exhalite unit in the Hart area has many characteristics that distinguish it from typical iron formation. The chert-rich nature with generally low Fe-oxide abundances and abnormally high sulfide and manganese contents suggest that the processes involved in the genesis of the exhalite unit may also differ from those for typical iron formations. model for the genesis of iron formation can be summarized as follows: oceans.

- Development of chert hardgrounds via infilling of pores or sediment replacement during early diagenesis at the sediment-water interface when delivery of iron and deposition of iron compounds slowed or stopped. 
This sequence of events typically produced a combination of geochemical characteristics in iron

453 formations such as: high $\mathrm{Y} /$ Ho ratio and positive Eu anomaly, which reflect transport and precipitation

454 from aqueous solutions with a strong hydrothermal input (Bolhar et al., 2004), slight HREE enrichment 455 (Bolhar et al., 2004; Planavsky et al., 2010), and positive $\delta^{56} \mathrm{Fe}$ values reflecting oxidation of Fe prior to 456 deposition (Rouxel et al., 2005; Bekker et al., 2010; Planavsky et al., 2012). Iron formations should also 457 have little to no synsedimentary sulfide present since iron formations reflect ferruginous rather than 458 euxinic water column conditions (Bekker et al., 2010).

The geochemistry and petrography of the exhalite unit in the Hart area suggests a somewhat different genesis. The negative, and highly variable, $\delta^{56} \mathrm{Fe}$ values from all samples, including those that resemble typical iron formation, are more commonly associated with sulfides from Archean organic matter-rich sediments or carbonate-facies iron formations than oxide-facies iron formations (e.g., Dauphas et al., 2017). Previous studies of Fe isotope fractionation have shown that precipitation of Fe-

464 sulfides from $\mathrm{Fe}^{2+}$ dissolved in an aqueous solution produces fractionations between -0.3 and $-0.9 \%$ in the temperature range of 2 to $40^{\circ} \mathrm{C}$ (Butler et al., 2005). Under hydrothermal conditions, nonequilibrium Fe isotope fractionation between pyrite in hydrothermal chimneys or Fe-sulfides in buoyant hydrothermal plume and hydrothermal fluid has been found to be about $-0.9 \%$ (Rouxel et al., 2008; Bennett et al., 2009; Rouxel et al., 2016). This suggests that the observed $\delta^{56} \mathrm{Fe}$ values of $-2.0 \%$ in 469 graphitic argillite and $-2.1 \%$ in exhalite were formed as a result of an additional pathway to decrease 470 the $\delta^{56} \mathrm{Fe}$ value of the water prior to precipitation of Fe-oxides in the exhalite unit, and are unlikely to

471 have been formed just by equilibrium or kinetic isotope fractionation during mineral precipitation in an 472 open aqueous system. Two mechanisms have been proposed to produce isotopically light $\mathrm{Fe}^{2+}$ in 473 solution, which could be recorded by Archean sedimentary rocks: 1) dissimilatory iron reduction in pore 474 waters by bacteria (Yamaguchi et al., 2005; Archer and Vance, 2006; Heinman et al., 2010), and 2) 475 reservoir effect resulting in Rayleigh-type fractionation due to the early precipitation of isotopically 
476

477

478

479

480

481

482

483

484

485

486

487

488

489

490

491

492

493

494

495

496

497

498

heavy Fe-oxides (Rouxel et al., 2005; Planavsky et al., 2012). A similar model based on Rayleigh

fractionation of Si isotopes was proposed by van den Boorn et al. (2010) to explain isotopic patterns in some Archean cherts.

On a plot of $\mathrm{Mn} / \mathrm{Fe}$ versus $\delta^{56} \mathrm{Fe}$ (Figure 13), no significant correlation is observed within the Hart data alone. However, when plotted with data from other Archean and early Paleoproterozoic iron formations (e.g., Tsikos et al., 2010; Planavsky et al., 2012, 2014), the exhalite data fits to a general pattern with $\mathrm{Mn}$-enriched samples $(\mathrm{Mn} / \mathrm{Fe}>0.01)$ having essentially negative $\delta^{56} \mathrm{Fe}$ values, and $\mathrm{Mn}$ depleted samples $(\mathrm{Mn} / \mathrm{Fe}<0.001)$ having positive $\delta^{56} \mathrm{Fe}$ values. The apparent dichotomy in $\delta^{56} \mathrm{Fe}$ values between $\mathrm{Mn}$-enriched and Mn-depleted samples is observed throughout several Archean to Paleoproterozoic units and is also observed in modern seafloor hydrothermal deposits (Rouxel et al., 2017). Although mechanisms for separation of $\mathrm{Mn}$ and Fe and for Fe isotope fractionation could have differed between pre-GOE and post-GOE deposits, the observed relationships between $\mathrm{Mn} / \mathrm{Fe}$ and $\delta^{56} \mathrm{Fe}$ values might be attributed to the increasing oxidation potential of the water column, leading to significant oxidation of Fe first and then $\mathrm{Mn}$. An increase in oxidation potential could explain why Mn/Fe ratios negatively correlate with $\delta^{56}$ Fe values, which might reflect extensive precipitation of isotopically heavy Fe-oxides in less oxidized settings. This process has been invoked for modern Fe-rich hydrothermal systems associated with volcanic seamounts such as Loihi (Rouxel et al., 2017). Additionally, although Eu anomalies are relatively large, the observed Eu anomalies in the Hart area are lower than the highest values recorded for BIFs and cherts from the Abitibi greenstone belt (as high as 31 in Thurston et al., 2012). As these Eu anomalies are generally attributed to the influence of hydrothermal input (e.g., Bolhar et al., 2004), the exhalite in the Hart area likely formed distally from the hydrothermal source relative to some of the BIFs sampled by Thurston et al. (2012). Applying this model to the Hart deposit exhalite unit (Figure 14) would suggest that both Feoxides and Fe-sulfides formed in distal hydrothermal plume environments, after significant iron 
depletion from solution. Precipitation of a relatively small amount of Fe-rich minerals with highly negative Fe isotope values, along with deposition of a small amount of clay minerals enriched in $\mathrm{Mn}$ oxyhydroxides and Mn-oxides that were later reacted with organic matter to form $\mathrm{Mn}$-carbonates, was followed by formation of chert hardgrounds developed in pores at or below the sediment-water interface and as a replacement of sediments. The observed positive anomalies for La, Gd, and high Y/Ho ratios all suggest precipitation from seawater, whereas both positive and negative $\mathrm{Ce}$ anomalies, pronounced positive Eu anomaly, high $\mathrm{Fe} / \mathrm{Ti}$, and low $\mathrm{Al} /(\mathrm{Al}+\mathrm{Fe}+\mathrm{Mn})$ ratios together suggest variable redox conditions in a deep-water setting straddling the redoxcline with strong hydrothermal input at the time of deposition (cf. Bolhar et al., 2004; Pecoits et al., 2009).

Petrographic evidence suggests that, following precipitation of chert, locally Fe-rich laminae were replaced by sulfides, as indicated by variable magnetite and pyrrhotite contents along laminae over 5-10 mm length. However, individual grains of magnetite do not show textures suggesting replacement by sulfides. This could suggest that sulfides replaced the primary Fe-oxyhydroxides prior to transformation of Fe-oxyhydroxides to magnetite during late diagenesis or metamorphism. The negative $\Delta^{33} \mathrm{~S}$ values and variable $\delta^{34} \mathrm{~S}$ values indicate that sulfides were formed through reduction, potentially bacterial, of sulfate likely derived from a nearly homogenous seawater reservoir. Considering the sign of the MIF anomaly, such sulfate reservoir was likely derived from sulfate formed via photochemical reactions in the Archean oxygen-free atmosphere (Ono et al., 2003). The formation of the sulfide phase in these Fe-rich laminae should have been limited by the availability of $\mathrm{H}_{2} \mathrm{~S}$, not $\mathrm{Fe}$, and as such, pyrrhotite formed instead of pyrite, as is the case in modern environments where availability of $S$ is the limiting factor (Kao et al., 2004; Larrasoana et al., 2007). Importantly, the pyrrhotite, or amorphous Fe monosulfide precursor to pyrrhotite, did not form at the same time as the exhalite precipitated, but are diagenetic products that must have crystallized before or at approximately the same time as chert precipitated, occluding permeability and porosity and halting bacterial sulfate reduction. Subsequent 
524

525

527

528

529

530

531

532

533

534

535

536

537

538

539

540

541

542

543

544

545

546

547

reaction, and recrystallization, of pyrrhotite to form pyrite could have occurred anaerobically under conditions of increased S availability or Fe-loss (Qian et al., 2011).

\section{Conclusions and Basin Scale Implications}

The low concentrations of $\mathrm{Zn}, \mathrm{U}$, and $\mathrm{U}_{\text {auth, }}$ and non-zero $\Delta^{33} \mathrm{~S}$ values all suggest that exhalite deposition in the Hart area of the Neoarchean Abitibi greenstone belt took place prior to the rise of atmospheric oxygen (cf. Farquhar et al., 2003; Scott et al., 2008, 2013; Partin et al., 2013a, b; Gumsley et al., 2017). However, Mn enrichment and highly negative Fe isotope values in both the exhalite and graphitic argillite require presence of oxygen at least in the upper part of the water column throughout the spreading path of the hydrothermal plume in a deep-water setting. Trace element data and $\delta^{56} \mathrm{Fe}$ values indicate that the exhalite formed with the significant influence of a hydrothermal fluid on water composition, although distally from the hydrothermal source with the regionally mapped BIF occurring more proximal to the hydrothermal source.

The presence of the interbedded exhalite and graphitic argillite suggests that these rocks were deposited in a relatively deep-water environment, as shown by their fine-grain size and absence of sedimentary structures indicative of deposition above the fair-weather and storm-wave base, possibly at the upslope transition from iron formation to black shales in the basinal profile proposed by Klein (2005), Beukes and Gutzmer (2008), and Bekker et al. (2010), representing shallower water depth than the stratigraphically equivalent BIFs elsewhere in the region. Fractionation of Fe isotopes during precipitation of Fe-oxyhydroxides could have resulted in the heavier isotopes being removed via deposition of iron formations in deeper parts of the basin, as represented by iron formations mapped at the correlative stratigraphic level elsewhere in the Shaw Dome (Houlé et al., 2010b; Figure 14). The basin margins sustained high organic productivity, as indicated by the abundance of carbon in the graphitic argillite. Due to deposition of the exhalite distally to the hydrothermal centres, the iron formation and exhalite in the Hart area are unusually chert-rich, with lower concentration of Fe-oxides, 
548

549

550

551

552

553

554

555

556

557

558

559

560

561

562

563

564

565

566

567

568

569

Fe-carbonates, and Fe-silicates than in typical iron formations. Early diagenetic bacterial sulfate reduction at the depositional site of exhalite led to the formation of significant amounts of sulfides, however, the limited availability of sulfur with respect to iron during deposition of the exhalite unit could have resulted in the formation of pyrrhotite instead of pyrite as the primary sulfide mineral. Our study indicates spatial and temporal variability of seawater redox conditions and chemical composition in Archean deep-water settings at $2.7 \mathrm{Ga}$, during a time when atmosphere stayed persistently anoxic.

\section{Acknowledgements}

We would like to express our appreciation to Northern Sun Mining Corp. (formerly Liberty Mines Ltd.)

for their logistical support, access to properties, information, and discussions with staff throughout this project. Financial support for this project has been provided by the Targeted Geoscience Initiative program of the Geological Survey of Canada and Natural Sciences and Engineering Research Council of Canada (NSERC) Discovery and Accelerator Grants to AB. OR acknowledges the technical support of Y.

Germain and E. Ponzevera (Ifremer) and funding from LabexMer (ANR-10-LABX-19-01). The McGill Stable Isotope Laboratory is supported by NSERC through Research Tools and Infrastructure and

Discovery Grants to BAW as well as operating funds from FQRNT through the GEOTOP research center.

We thank Dr. Boswell Wing and Thi Hao Bui for technical assistance in the McGill Stable Isotope Laboratory.

Alibo, D.S., Nozaki, Y. 1999. Rare earth elements in seawater: particle association, shale-normalization, and Ce oxidation. Geochimica et Cosmochimica Acta 63, 363-372.

Alt, J.C. 1995. Sulfur isotopic profile through the oceanic crust: Sulfur mobility and seawater-crustal sulfur exchange during hydrothermal alteration. Geology 23, 585-588. 
Anbar, A.D., Duan, Y., Lyons, T.W., Arnold, G.L., Kendall, B., Creaser, R.A., Kaufman, A.J., Gordon, G.W., Scott, C., Garvin, J., Buick, R. 2007. A whiff of oxygen before the great oxidation event? Science 317, 1906-1906.

Archer, C., Vance, D. 2006. Coupled Fe and S isotope evidence for Archean microbial Fe(III) and sulfate reduction. Geology 42, 153-156.

Ayer, J., Amelin, Y., Corfu, F., Kamo, S., Ketchum, J., Kwok, K., Trowell, N. 2002. Evolution of the southern Abitibi greenstone belt based on $\mathrm{U}-\mathrm{Pb}$ geochronology: autochthonous volcanic construction followed by plutonism, regional deformation and sedimentation. Precambrian Research 115, $63-$ 95.

Ayer, J.A., Thurston, P.C., Bateman, R., Dubé, B., Gibson, H.L., Hamilton, M.A., Hathway, B., Hocker, S.M., Houlé, M.G., Hudak, G., Ispolatov, V.O., Lafrance, B., Lesher, C.M., MacDonald, P.J., Péloquin, A.S., Piercey, S.J., Reed, L.E., Thompson, P.H. 2005. Overview of results from the Greenstone Architecture Project: Discover Abitibi Initiative; Ontario Geological Survey, Open File Report $6154,146 \mathrm{p}$.

Balci, N., Bullen, T.D., Witte-Lien, K., Shanks, W.C., Motelica, M., Mandernack, K.W. 2006. Iron isotope fractionation during microbially stimulated Fe(II) oxidation and Fe(III) precipitation. Geochimica et Cosmochimica Acta 70, 622-639.

Barrie, C.T. 2005. Geochemistry of exhalites and graphitic argillites near VMS and gold deposits: Ontario Geological Survey Miscellaneous Release Data 173, 126 p.

Bau, M. 1999. Scavenging of dissolved yttrium and rare earths by precipitation iron oxyhydroxide: Experimental evidence for Ce oxidation, Y-Ho fractionation, and lanthanide tetrad effect. Geochimica et Cosmochimica Acta 63, 67-77.

Bau, M., Dulski, P. 1996. Distribution of yttrium and rare-earth elements in the Penge and Kuruman ironformations, Transvaal Supergroup, South Africa. Precambrian Research 79, 37-55. 
Beard, B., Handler, R.M., Scherer, M.M., Wu, L., Czaja, A.D., Heimann, A., Johnson, C.M. 2010. Iron isotope fractionation between aqueous ferrous iron and goethite. Earth and Planetary Science Letters 295, 241-250.

Beard, B.L., Johnson, C.M., Skulan, J.L., Nealson, K.H., Cox, L., Sun, H. 2003. Application of Fe isotopes to tracing the geochemical and biological cycling of Fe. Chemical Geology 195, 87-117.

Bekker, A., Holland, H.D., Wang, P.-L., Rumble III, D., Stein, H.J., Hannah, J.L., Coetzee, L., Beukes, N.J. 2004. Dating the rise of atmospheric oxygen. Nature 427, 117-120.

Bekker, A., Barley, M.E., Fiorentini, M.L., Rouxel, O.J., Rumble, D., Beresford, S.W. 2009. Atmospheric sulfur in Archean komatiite-hosted nickel deposits. Science 326, 1086-1089.

Bekker, A., Slack, J.F., Planavsky, N., Krapež, B., Hofmann, A., Konhauser, K.O., Rouxel, O.J. 2010. Iron formation: the sedimentary product of a complex interplay among mantle, tectonic, oceanic, and biospheric processes. Economic Geology 105, 467-508.

Bekker, A., Planavsky, N., Krapež, B., Rasmussen, B., Hofmann, A., Slack, J.F., Rouxel, O.J., Konhauser, K.O. 2013, Iron Formations: Their Origins and Implications for Ancient Seawater Chemistry, Treatise of Geochemistry, Elsevier, v. 9, p. 561-628.

Bennett, S.A., Rouxel, O., Schmidt, K., Garbe-Schonberg, D., Statham, P.J., German, C.R. 2009. Iron isotope fractionation in a buoyant hydrothermal plume, 5 degrees S Mid-Atlantic Ridge. Geochimica et Cosmochimica Acta 73, 5619-5634.

Beukes, N.J., Gutzmer, J. 2008. Origin and paleoenvironmental significance of major iron formations at the Archean-Paleoproterozoic boundary; in Banded iron formation-related high-grade iron ore, Society of Economic Geologists, Reviews in Economic Geology 15, 5-47.

Bjerrum, C.J., Canfield, D.E. 2002. Ocean productivity before about $1.9 \mathrm{Gyr}$ ago limited by phosphorus adsorption onto iron oxides. Nature 417, 159-162. 
Bolhar, R., Kamber, B.S., Moorbath, S., Fedo, C.M., Whitehouse, M.J. 2004. Characterization of early Archaean chemical sediments by trace element signatures. Earth and Planetary Science Letters $222,43-60$.

Bonatti, E., Kraemer, T, Rydell, H.S. 1972. Classification and genesis of submarine iron-manganese deposits. In: Ferromanganese deposits on the ocean floor. IDOE, Columbia Univ. N.Y. p.149-166.

Böstrom, K., Peterson, M.N.A., Joensuu, O., Fisher, D.E. 1969. Aluminum-poor ferromanganoan sediments on active oceanic ridges. Journal of Geophysical Research 74, 3261.

Böstrom, K., Kraemer, T., Gartner, S. 1973. Provenance and accumulation rates of opaline silica, Al, Ti, $\mathrm{Fe}, \mathrm{Mn}, \mathrm{Cu}, \mathrm{Ni}$ and $\mathrm{Co}$ in Pacific pelagic sediments. Chemical Geology 11, 123-148.

Brunner, B., Bernasconi, S.M. 2005. A revised isotope fractionation model for dissimilatory sulfate reduction in sulfate reducing bacteria. Geochimica et Cosmochimica Acta 69, 4759-4771.

Busigny, V., Planavsky, N.J., Jezequel, D., Crowe, S., Louvat, P., Moureau, J., Viollier, E., Lyons, T.W. 2014. Iron isotopes in an Archean ocean analogue. Geochimica et Cosmochimica Acta 133, 443-462.

Butler, I.B., Archer, C., Vance, D., Oldroyd, A., Rickard, D. 2005. Fe isotope fractionation on FeS formation in ambient aqueous solution. Earth and Planetary Science Letters 236, 430-442.

Byrne, R.H., Sholkovitz, E.R. 1996. Chapter 158. Marine chemistry and geochemistry of the lathanides. In: Gschneidner Jr., K.A., LeRoy, E. (Eds.). Handbook on the Physics and Chemistry of the Rare Earths. Elsevier, pp. 497-593.

Chever, F., Rouxel, O., Croot, P.L., Ponzevera, E., Wuttig, K., Auro, M. 2015. Total dissolvable and dissolved iron isotopes in the water column of the Peru upwelling regime. Geochimica et Cosmochimica Acta, 162, 66-82.

Coplen, T.B., Krouse, H.R. 1998. Sulphur isotope data consistency improved. Nature 392, 32.

Croal, L.R., Johnson, C.M., Beard, B.L., Newman, D.K. 2004. Iron isotope fractionation by Fe(II)-oxidizing photoautotrophic bacteria. Geochimica et Cosmochimica Acta 68, 1227-1242. 
641

642

643

644

645

646

647

648

649

650

651

652

653

654

655

656

657

658

659

660

661

662

663

Crosby, H.A., Roden, E.E., Johnson, C.M., Beard, B.L. 2007. The mechanisms of iron isotope fractionation produced during dissimilatory Fe(III) reduction by Shewanella putrefaciens and Geobacter sulfurreducens. Geobiology 5, 169-189.

Dauphas, N., John, S., Rouxel, O. 2017. Iron Isotope Systematics. Reviews in Mineralogy \& Geochemistry $82415-510$.

Detmers, J., Bruchert, V., Habicht, K.S., Kuever, J. 2001. Diversity of sulfur isotope fractionation by sulfate-reducing prokaryotes. Applied and Environmental Microbiology, 67, 888-894.

Duan, Y., Severmann, S., Anbar, A.D., Lyons, T.W., Gordon, G.W., Sageman, B.B. 2010. Isotopic evidence for Fe cycling and repartitioning in ancient oxygen-deficient settings: Examples from black shales of the mid-to-late Devonian Appalachian basin. Earth and Planetary Science Letters 290, 244253.

Farquhar, J., Wing, B.A. 2003. Multiple sulfur isotopes and the evolution of the atmosphere. Earth and Planetary Science Letters 213, 1-13.

Farquhar, J., Bao, H., Thiemens, M. 2000. Atmospheric influence of Earth's earliest sulfur cycle. Science $289,756-758$.

Farquhar, J., Savarino, J., Airieau, S., Thiemens, M.H. 2001. Observation of wavelength-sensitive massindependent sulfur isotope effects during $\mathrm{SO}_{2}$ photolysis: Implications for the early atmosphere. Journal of Geophysical Research 106, 32829-32839.

Farquhar, J., Wing, B.A., McKeegan, K.D., Harris, J.W., Cartigny, P., Thiemens, M.H. 2002. Massindependent sulfur of inclusions in diamond and sulfur recycling on early earth. Science 298, 2369-2372.

Fralick, P., Riding, R. 2015. Steep Rock Lake: Sedimentology and geochemistry of an Archean carbonate platform. Earth-Science Reviews 151, 132-175. 
664 665 666 667 668 669 670 671 672 673 675 676

German, C.R., Holliday, B.P., Elderfield, H. 1991. Redox cycling of rare earth elements in the suboxic zone of the Black Sea. Geochimica et Cosmochimica Acta 55, 3553-3558.

Guilbaud, R., Butler, I.B., Ellam, R.M. 2011. Abiotic Pyrite Formation Produces a Large Fe Isotope Fractionation. Science 332, 1548-1551.

Gumsley, A.P., Chamberlain, K.R., Bleeker, W., Söderlund, U., de Kock, M.O., Larsson, E.R., Bekker, A. 2017. Timing and tempo of the great oxidation event. Proceedings of the National Academy of the Sciences 114, 1811-1816.

Habicht, K.S., Gade, M., Thamdrup, B., Berg, P., Canfield, D.E. 2002. Calibration of the sulfate levels in the Archean ocean. Science 298, 2372-2374.

Haogaard, R., Ootes, L., Konhauser, K. 2017. Neoarchaean banded iron formation within a 2620 Ma turbidite-dominated deep water basin, Slave craton, NW Canada. Precambrian Research 292, 130-151.

Heimann, A., Johnson, C.M., Beard, B.L., Valley, J.W., Roden, E.E., Spicuzza, M.J., Beukes, N.J. 2010. Fe, C, and $\mathrm{O}$ isotope compositions of banded iron formation carbonates demonstrate a major role for dissimilatory iron reduction in $\sim 2.5$ Ga marine environments. Earth and Planetary Science Letters 294, 8-18.

Hiebert, R.S., Bekker, A., Wing, B.A., Rouxel, O.J. 2013. The role of paragneiss assimilation in the origin of the Voisey's Bay Ni-Cu sulfide deposit, Labrador: multiple S and Fe isotope evidence. Economic Geology 108, 1459-1469.

Hiebert, R.S., Bekker, A., Houlé, M.G., Wing, B.A., Rouxel, O.J. 2016. Tracing sources of crustal contamination using multiple $\mathrm{S}$ and Fe isotopes in the Hart komatiite-associated $\mathrm{Ni}-\mathrm{Cu}-(\mathrm{PGE})$ sulphide deposit, Abitibi greenstone belt, Ontario, Canada. Mineralium Deposita 51, 919-935. 
686

687

688

689

690

691

692

693

694

695

696

697

698

699

700

701

702

703

704

705

706

707

708

Houlé, M.G., Lesher, C.M. 2011. Komatiite-associated Ni-Cu-(PGE) deposits, Abitibi greenstone belt, Superior Province, Canada; in Magmatic Ni-Cu and PGE deposits: geology, geochemistry, and genesis. Society of Economic Geologists, Reviews in Economic Geology 17, 89-121.

Houlé, M.G., Lesher, C.M., Gibson, H.L., Ayer, J.A., Hall, L.A.F. 2010a. Localization of komatiite-associated $\mathrm{Ni}-\mathrm{Cu}$-(PGE) deposits in the Shaw Dome, Abitibi greenstone belt, Superior Province. In:

Abstracts, 11th International Platinum Symposium, 21-24 June 2010, Sudbury, Ontario, Canada, Ontario Geological Survey, Miscellaneous Release-Data 269.

Houlé, M.G., Lesher, C.M., Préfontaine, S., Ayer, J.A., Berger, B.R., Taranovic, V., Davis, P.C., Atkinson, B. 2010b. Stratigraphy and physical volcanology of komatiites and associated Ni-Cu-(PGE) mineralization in the western Abitibi greenstone belt, Timmins area, Ontario: a field trip for the 11th International Platinum Symposium; Ontario Geological Survey, Open File Report 6255, 99p

Isley, A. 1995. Hydrothermal plumes and the delivery of iron to banded iron formations. Journal of Geology 103, 169-185.

Jamieson, J.W., Wing, B.A., Farquhar, J., Hannington, M.D. 2013. Neoarchean seawater sulphate concentrations from sulphur isotopes in massive sulphide ore. Nature Geoscience 6, 61-64.

Johnston, D.T., Farquhar, J., Wing, B.A., Kaufman, A.J., Canfield, D.E., Habicht, K.S. 2005. Multiple sulfur isotope fractionations in biological systems: A case study with sulfate reducers and sulfur disproportionators. American Journal of Science 305, 645-660.

Kamber, B.S. 2010. Archean mafic-ultramafic volcanic landmasses and their effect on ocean-atmosphere chemistry. Chemical Geology 274, 19-28.

Kao, S.-J., Horng, C.-S., Roberts, A.P., Liu, K.-K. 2004. Carbon-sulfur-iron relationships in sedimentary rocks from southwestern Taiwan: influence of geochemical environment on greigite and pyrrhotite formation. Chemical Geology 203, 153-168. 
709

710

711

712

713

714

715

716

717

718

719

720

721

722

723

724

725

726

727

728

729

730

Kaufman, A.J., Johnston, D.T., Farquhar, J., Masterson, A.L., Lyons, T.W., Bates, S., Anbar, A.D., Arnold, G.L., Garvin, J., Buick, R. 2007. Late Archean biospheric oxygenation and atmospheric evolution. Science 317, 1900-1903.

Kato, Y., Yamaguchi, K.E., Ohmoto, H. 2006. Rare earth elements in Precambrian banded iron formations: Secular changes of $\mathrm{Ce}$ and Eu anomalies and evolution of atmospheric oxygen. Geological Society of America Memoir 198, 269-289.

Ketchum, J.W.F., Ayer, J.A., Van Breemen, O. 2008. Pericontinental Crustal Growth of the southwestern Abitibi Subprovince, Canada: U-Pb, Hf, and Nd Isotopic Evidence. Economic Geology 103, 11511184.

Klein, C. 2005. Some Precambrian banded iron-formations (BIFs) from around the world: Their age, geologic setting, mineralogy, metamorphism, geochemistry, and origin. American Mineralogist 90, 1473-1499.

Konhauser, K.O., Lalonde, S.V., Planavsky, N.J., Pecoits, E., Lyons, T.W., Mojzsis, S.J., Rouxel, O.J., Barley, M.E., Rosiere, C., Fralick, P.W., Kum, L.R., Bekker, A. 2011. Aerobic bacterial pyrite oxidation and acid rock drainage during the Great Oxidation Event. Nature 478, 369-373.

Kurzweil, F., Wille, M., Gantert, N., Beukes, N.J., Schoenberg, R. 2016. Manganese oxide shuttling in preGOE oceans - evidence from molybdenum and iron isotopes. Earth and Planetary Science Letters 452, 69-78.

Lalonde, S.V., Konhauser, K.O. 2015. Benthic perspective on Earth's oldest evidence for oxygenic photosynthesis. Proceedings of the National Academy of Sciences 112, 995-1000.

Lantink, M.L., Oonk, P.B.H., Floor, G.H., Tsikos, H., Mason, P.R.D. 2018. Fe isotopes of a 2.4 Ga hematiterich IF constrain marine redox conditions around the GOE. Precambrian Research 305, 218-235. 
731

732

733

734

735

736

737

738

739

740

741

742

743

744

745

746

747

748

749

750

751

752

753

754

Larrasoana J.C., Roberts, A.P., Musgrave, R.J., Gracia, E., Pinero, E., Vega, M., Martinez-Ruiz, F. 2007. Diagenetic formation of greigite and pyrrhotite in gas hydrate marine sedimentary systems. Earth and Planetary Science Letters 261, 350-366.

Li, W.Q., Beard, B.L., Johnson, C.M. 2015. Biologically recycled continental iron is a major component in banded iron formations. Proceedings of the National Academy of Sciences of the United States of America 112, 8193-8198.

Lough, A.J.M., Klar, J.K., Homoky, W.B., Comer-Warner, S.A., Milton, J.A., Connelly, D.P., James, R.H., Mills, R.A. 2017. Opposing authigenic controls on the isotopic signature of dissolved iron in hydrothermal plumes. Geochimica et Cosmochimica Acta 202, 1-20.

Lyons, T.W., Reinhard, C.T., Planavsky, N.J. 2014. The rise of oxygen in Earth's early ocean and atmosphere. Nature 506, 307-315.

Marin-Carbonne, J., Rollion-Bard, C., Bekker, A., Rouxel, O., Agangi, A., Cavalazzi, B., WohlgemuthUeberwasser, C.C. 2014. Coupled Fe and S isotope variations in pyrite nodules from Archean shale. Earth and Planetary Science Letters 392, 67-79.

Maynard, J.B., 2010. The chemistry of manganese ores through time: a signal of increasing diversity of earth-surface environments. Economic Geology 105, 535-552.

Maynard, J.B., Sutton, S.J., Rumble III, D., Bekker, A. 2013. Mass-independently fractionated sulfur in Archean paleosols: a large reservoir of negative $\Delta^{33} \mathrm{~S}$ anomaly on the early Earth. Chemical Geology 362, 74-81.

Mendes, M., Lobato, L.M., Kunzmann, M., Halverson, G.P., Rosiere, C.A. 2016. Iron isotope and REE+Y composition of the Caue banded iron formation and related iron ores of the Quadrilaero Ferrifero, Brazil. Mineralium Deposita published online.

Olson, S.L., Kump, L.R., Kasting, J.F. 2013. Quantifying the areal extent and dissolved oxygen concentrations of Archean oxygen oases. Chemical Geology 362, 35-43. 
Ono, S., Eigenbrode, J.L., Pavlov, A.A., Kharecha, P., Rumble III, D., Kasting, J.F., Freeman, K.H. 2003. New insights into Archean sulfur cycle from mass-independent sulfur isotope records from the Hamersley Basin, Australia. Earth and Planetary Science Letters 213, 15-30.

Ono, S., Beukes, N.J., Rumble, D. 2009. Origin of two distinct multiple-sulfur isotope compositions of pyrite in the 2.5 Ga Klein Naute Formation, Griqualand West Basin, South Africa. Precambrian Research 169, 48-57.

Ossa Ossa, F., Hofmann, A., Vidal, O., Kramers, J.D., Belyanin, G., Cavalazzi, B. 2016. Unusual manganese enrichment in the Mesoarchean Mozaan Group, Pongola Supergroup, South Africa. Precambrian Research 281, 414-433.

Partin, C.A., Bekker, A., Planavsky, N.J., Scott, C.T., Gill, B.C., Podkovyrov, V., Maslov, A., Konhauser, K.O., Lalonde, S.V., Love, G.D., Poulton, S.W., Lyons, T.W. 2013a. Large-scale fluctualtions in Precambrian atmospheric and oceanic oxygen levels from the record of $U$ in shales. Earth and Planetary Science Letters 369-370, 284-293.

Partin, C.A., Lalonde, S.V., Planavsky, N.J., Bekker, A., Rouxel, O.J., Lyons, T.W., Konhauser, K.O. 2013b. Uranium in iron formations and the rise of atmospheric oxygen. Chemical Geology 362, 82-90.

Pavlov, A.A., Kasting, J.F. 2002. Mass-Independent Fractionation of Sulfur Isotopes in Archean Sediments: Strong Evidence for an Anoxic Archean Atmosphere. Astrobiology 2, 27-41.

Pecoits, S., Gingras, M.K., Barley, M.E., Kappler, A., Posth, N.R., Konhauser, K.O. 2009. Petrography and geochemistry of the Dales Gorge banded iron formation: Paragenetic sequence, source and implications for palaeo-ocean chemistry. Precambrian Research 172, 163-187.

Percak-Dennett, E.M., Beard, B.L., Xu, H., Konishi, H., Johnson, C.M., Roden, E.E. 2011. Iron isotope fractionation during microbial dissimilatory iron oxide reduction in simulated Archaean seawater. Geobiology 9, 205-220. 
778

779

780

781

782

783

784

785

786

787

788

789

790

791

792

793

794

795

796

797

798

799

Planavsky, N., Bekker, A., Rouxel, O.J., Kamber, B., Hofmann, A., Knudsen, A., Lyons, T.W. 2010. Rare Earth Element and yttrium compositions of Archean and Paleoproterozoic Fe formations revisited: New perspectives on the significance and mechanisms of deposition. Geochimica et Cosmochimica Acta 74, 6387-6405.

Planavsky, N., Rouxel, O.J., Bekker, A., Hofmann, A., Little, C.T.S., Lyons, T.W. 2012. Iron isotope composition of some Archean and Proterozoic iron formations. Geochimica et Cosmochimica Acta 80, 158-169.

Planavsky, N.J., Asael, D., Hofmann, A., Reinhard, C.T., Lalonde, S.V., Knudsen, A., Wang, X., Ossa Ossa, F., Pecoits, E., Smith, A.J.B., Beukes, N., Bekker, A., Johnson, T.M., Konhauser, K.O., Lyons, T.W., Rouxel, O.J. 2014. Evidence for oxygenic photosynthesis half a billion years before the Great Oxidation Event. Nature Geosciences 7, 283-286.

Qian, G., Xia, F., Brugger, J., Skinner, W.M., Bei, J., Chen, G., Pring, A. 2011. Replacement of pyrrhotite by pyrite and marcasite under hydrothermal conditions up to $220^{\circ} \mathrm{C}$ : An experimental study of reaction textures and mechanisms. American Mineralogist 96, 1878-1893.

Reinhard, C.T., Raiswell, R., Scott, C., Anbar, A.D., Lyons, T.W., 2009. A late Archean sulfidic sea stimulated by early oxidative weathering of the continents. Science 326, 713-716.

Reinhard, C.T., Planavsky, N.J., Gill, B.C., Ozaki, K., Robbins, L.J., Lyons, T.W., Fischer, W.W., Wang, C.J., Cole, D.B., Konhauser, K.O. 2017. Evolution of the global phosphorus cycle. Nature 541, 386-389.

Riding, R., Fralick, P., Liang, L. 2014. Identification of an Archean marine oxygen oasis. Precambrian Research 251, 232-237.

Ridler, R.H. 1971. Analysis of Archean volcanic basins in the Canadian Shield using the exhalite concept. Bulletin of the Canadian Institute of Mining and Metallurgy 64, 20. 
800

801

802

803

804

805

806

807

808

809

810

811

812

813

814

815

816

817

818

819

820

821

822

823

Ripley, E.M. 1999. Systematics of sulphur and oxygen isotopes in mafic igneous rocks and Cu-Ni-PGE mineralization; in Dynamic processes in magmatic ore deposits and their application in mineral exploration. Geological Association of Canada, Short Course Notes, v.13, p.111-158.

Robbins, L.J., Lalonde, S.V., Saito, M.A., Planavsky, N.J., Mloszewska, A.M., Pecoits, E., Scott, C., Dupont, C.L., Kappler, A., Konhauser, K.O. 2013. Authigenic iron oxide proxies for marine zinc over geological time and implications for eukaryotic metallome evolution. Geobiology 11, 295-306.

Rouxel, O., Dobbek, N., Ludden, J., Fouquet, Y. 2003. Iron isotope fractionation during oceanic crust alteration. Chemical Geology 202, 155-182.

Rouxel, O.J., Bekker, A., Edwards, K.J. 2005. Iron isotope constraints of the Archean and Paleoproterozoic ocean redox state. Science 307, 1088-1091.

Rouxel, O., Shanks III, W.C., Bach, W. and Edwards, K.J. 2008. Integrated Fe- and S-isotope study of seafloor hydrothermal vents at East Pacific Rise $9-10^{\circ} \mathrm{N}$. Chemical Geology 252, 214-227

Rouxel, O., Sholkovitz, E., Charette, M., Edwards, K.J. 2008. Iron isotope fractionation in subterranean estuaries. Geochimica et Cosmochimica Acta, 72, 3413-3430.

Rouxel, O., Toner, B.M., Manganini, S.J., German, C.R. 2016. Geochemistry and iron isotope systematics of hydrothermal plume fall-out at East Pacific Rise 9 degrees 50 ' N. Chemical Geology 441, 212234.

Rouxel, O., Toner, B., Germain, Y., Glazer, B. 2017. Geochemical and iron isotopic insights into hydrothermal iron oxyhydroxide deposit formation at Loihi Seamount. Geochimica et Cosmochimica Acta, in revision.

Rudnick, R.L., Gao, S. 2014. Composition of the Continental Crust. Treatise on Geochemistry (Second Edition) 4, 1-51.

Scott, C., Lyons, T.W., Bekker, A., Shen, Y., Poulton, S.W., Chu, X., Anbar, A.D. 2008. Tracing the stepwise oxygenation of the Proterozoic ocean. Nature 452, 456-459. 
Scott, C., Planavsky, N.J., Dupont, C.L., Kendall, B., Gill, B.C., Robbins, L.J., Husband, K.F., Arnold, G.L., Wing, B.A., Poulton, S.W., Bekker, A., Anbar, A.D., Konhauser, K.O., Lyons, T.W. 2013. Bioavailability of zinc in marine systems through time. Nature Geoscience 6, 125-128.

Severmann, S., Lyons, T.W., Anbar, A., McManus, J., Gordon, G. 2008. Modern iron isotope perspective on the benthic iron shuttle and the redox evolution of ancient oceans. Geology 36, 487-490.

Slack, J.F., Grenne, T., Bekker, A., Rouxel, O.J., Lindberg, P.A. 2007. Suboxic deep seawater in the late Paleoproterozoic: Evidence from hematitic chert and iron formation related to seafloorhydrothermal sulfide deposits, central Arizona, USA. Earth and Planetary Science Letters 255, 243-256.

Steinhoefel, G., Horn, I., von Blanckenburg, F. 2009. Micro-scale tracing of Fe and Si isotope signatures in banded iron formation using femtosecond laser ablation. Geochimica et Cosmochimica Acta 60, 4957-4963.

Swanner, E.D., Planavsky, N.J., Lalonde, S.V., Robbins, L.J., Bekker, A., Rouxel, O.J., Saito, M.A., Kappler, A., Mojzsis, S.J., Konhauser, K.O. 2014. Cobalt and marine redox evolution. Earth and Planetary Science Letters 390, 253-263.

Swanner, E.D., Wu, W.F., Schoenberg, R., Byrne, J., Michel, F.M., Pan, Y.X., Kappler, A. 2015. Fractionation of Fe isotopes during Fe(II) oxidation by a marine photoferrotroph is controlled by the formation of organic Fe-complexes and colloidal Fe fractions. Geochimica et Cosmochimica Acta,, 165, 44-61.

Tangalos, G.E., Beard, B.L., Johnson, C.M., Alpers, C.N., Shelobolina, E.S., Xu, H., Konishi, H., Roden, E.E. 2010. Microbial production of isotopically light iron(II) in a modern chemically precipitated sediment and implications for isotopic variations in ancient rocks. Geobiology 8, 197-208. 
Thompson, P.H. 2005. A new metamorphic framework for gold exploration in the Timmins-Kirkland Lake area, western Abitibi greenstone belt: Discover Abitibi Initiative; Ontario Geological Survey, Open File Report 6162, 104p.

Thurston, P.C., Chivers, K.M. 1990. Secular variation in greenstone sequence development emphasizing Superior Province, Canada. Precambrian Research 46, 21-58.

Thurston, P.C., Ayer, J.A., Goutier, J., Hamilton, M.A. 2008. Depositional gaps in Abitibi greenstone belt stratigraphy: a key to exploration for syngenetic mineralization. Economic Geology 103, 10971134.

Thurston, P.C., Kamber, B.S., Whitehouse, M. 2012. Archean cherts in banded iron formation: insight into Neoarchean ocean chemistry and depositional processes. Precambrian Research 214-215, 227-257.

Tsikos, H., Matthews, A., Erel, Y., Moore, J.M. 2010. Iron isotopes constrain biochemical redox cycling of iron and manganese in a Palaeoproterozoic stratified basin. Earth and Planetary Science Letters $298,125-134$.

van den Boorn, S.H.J.M., van Bergen, M.J., Vroon, P.Z., de Vries, S.T., Nijman, W. 2010. Silicon isotope and trace element constraints on the origin of 3.5 Ga cherts: Implications for Early Archaean marine environments. Geochimica et Cosmochimica Acta 74, 1077-1103.

von Blanckenburg, F., Mamberti, M., Schoenberg, R., Kamber, B.S., Webb, G.E. 2008. The iron isotope composition of a microbial carbonate. Chemical Geology 249, 113-128.

Wu, L.L., Beard, B.L., Roden, E.E., Johnson, C.M. 2011. Stable Iron Isotope Fractionation Between Aqueous Fe(II) and Hydrous Ferric Oxide. Environ. Sci. Technol., 45, 1847-1852.

Yamaguchi, K.E., Johnson, C.M., Beard, B.L., Ohmoto, H. 2005. Biogeochemical cycling of iron in the Archean-Paleoproterozoic Earth: Constraints from iron isotope variations in sedimentary rocks from the Kaapvaal and Pilbara Cratons. Chemical Geology 218, 135-169. 
872 Figure 1: Geological map of the Shaw Dome, Abitibi greenstone belt (modified from Houlé et al., 2010a, b).

873 Figure 2: Geologic map of the Hart deposit area (modified from Houlé et al., 2010b). Drill hole collar locations are indicated.

874 Locations of sampled surface trenches are indicated by the green bars.

875 Figure 3: a-b Outcrop photographs of the exhalite unit, taken along strike from the Hart area; chert (a) and iron formation (b)

876 lithologies. The coin is $18 \mathrm{~mm}$ in diameter on figures a and b. c-d Reflected light photomicrographs of exhalite in the footwall of the Hart deposit: oxide-rich laminae in chert (c: sample H11-13C-363) and fine pyrrhotite grains replaced by coarse pyrite grains containing inclusions of pyrrhotite (circled) in a barren sulfide lens within the exhalite unit (d: sample H11-08-58.3).

Figure 4: a Core photo of graphitic argillite, showing nodules and bands of pyrite intercalated with chert-rich exhalite above and below. The coin is $18 \mathrm{~mm}$ in diameter. b Photomicrographs of graphitic argillite in plane-polarized light, showing quartz (white) and chlorite (grey), and opaque graphite and pyrite (sample H11-13C-357.1).c Photomicrograph in reflected light of

882 pyrite nodule in graphitic argillite, showing growth in concentric bands (sample H11-13C-357.1). d Photomicrograph of graphitic argillite unit in reflected light (sample H11-13C-366.1), showing minor disseminated pyrite (bright grains), opaque mineral

884 (graphite), and silicates (light grey).

Figure 5: Approximate fields of $\Delta^{33} \mathrm{~S}$ and $\delta^{34} \mathrm{~S}$ values for the different volcanic, atmospheric, and seawater $\mathrm{S}$ pools in the Archean. Purple oval represents composition of mantle-derived volcanic sulfur; blue oval and red circle represent composition of reduced sulfur $\left(\mathrm{S}_{8}\right)$ and oxidized sulfur $\left(\mathrm{SO}_{4}{ }^{2-}\right)$, respectively. Orange dashed line represents the most likely range in composition of sulfides formed by sulfate-reducing bacteria (SRB) that resulted in a horizontal shift in seawater sulfate composition to higher $\delta^{34} S$ values (red oval; fields are after Ono et al. 2003).

890 Figure 6: Ce anomalies (a), and rare earth element patterns (b) of exhalite samples (see Table 3 for method of calculation of Ce 891 and La anomalies).

892 Figure 7: Ce anomalies (a), and rare earth element patterns (b) for graphitic argillite samples (see Table 3 for method of 893 calculation of Ce and La anomalies).

894 Figure 8: Back-scattered electron image of exhalite sample H11-08-63.9, showing the Mn-bearing minerals and the EDS spectra.

895 Chl: chlorite, Act: actinolite, and Cal: calcite. White minerals on image are dense Fe-oxide and sulfide minerals.

896 Figure 9: Sulfur isotope signature of the Hart area exhalite and graphitic argillite. Red line in (a) indicates terrestrial

897 fractionation line (TFL; Farquhar and Wing, 2003). Terrestrial fractionation line corresponds to $\Delta^{33} \mathrm{~S}=0 \%$ jn (b). 
Figure 11: Plot of S concentration vs. $\delta^{56} \mathrm{Fe}$ values shows no correlation, indicating that Fe isotope values are not controlled by

901 sulfide content.

902 Figure 12: Diagrams designed to test the significance of detrital input on composition of sedimentary rocks. A positive

903 correlation in (a) and (b) indicates some compositional control by detrital material on the graphitic argillite. In (c), plotting in

904 zone I indicates a dominantly hydrothermal source for sediments, plotting in zone II indicates some influence of a hydrothermal

905 source mixed with detrital material, and plotting in zone III indicates a dominantly detrital source (Peciots et al., 2009).

906 Figure 13: Exhalite data from this study broadly follows the same negative correlation trend as observed from several iron

907 formations through time, including the Paleoproterozoic Hotazel Formation, South Africa (Tsikos et al., 2010), the Archean

908 Senqeni Formation, South Africa (Planavsky et al., 2014), and several other well-preserved Archean and Paleoproterozoic iron

909 formations compiled by Planavsky et al. (2012).

910 Figure 14: Cartoon cross-section showing the location of the Hart area within the basin during deposition. Iron formations were

911 deposited deeper in the basin, with heavier Fe-isotope values, and the Hart exhalite and graphitic argillite formed upslope in a

912 zone of upwelling (based on the models of Klein 2005, Beukes and Gutzmer 2008, and Bekker et al., 2010). 
914 Table 1.

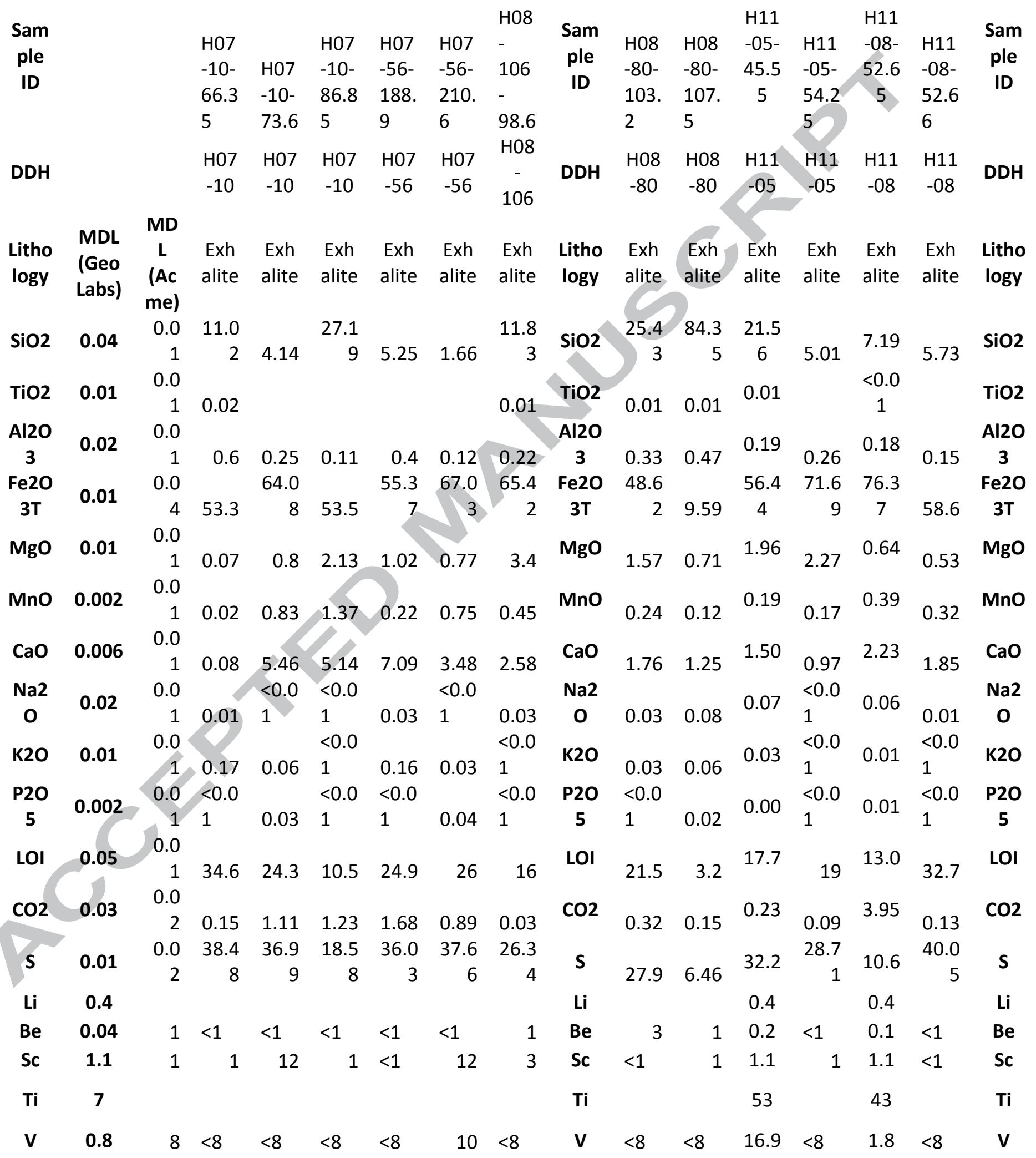




\begin{tabular}{|c|c|c|c|c|c|c|c|c|c|c|c|c|c|c|c|c|}
\hline $\mathrm{Cr}$ & 3 & & & & & & & & $\mathrm{Cr}$ & & & 11 & & 4 & & $\mathrm{Cr}$ \\
\hline Co & 0.13 & 0.2 & 51.7 & 41.3 & 16 & 93 & 71.7 & 93.5 & Co & 73.6 & 3.7 & $\begin{array}{c}130 . \\
48\end{array}$ & 98.4 & $\begin{array}{c}96.8 \\
9\end{array}$ & 93.3 & Co \\
\hline $\mathbf{N i}$ & 1.6 & 0.1 & $\begin{array}{r}119 . \\
1\end{array}$ & 40.7 & 42.6 & $\begin{array}{r}109 . \\
6\end{array}$ & $\begin{array}{r}140 . \\
4\end{array}$ & $\begin{array}{r}149 . \\
6\end{array}$ & $\mathrm{Ni}$ & $\begin{array}{r}317 \\
2.6\end{array}$ & $\begin{array}{r}261 . \\
3\end{array}$ & $\begin{array}{c}980 . \\
4\end{array}$ & $\begin{array}{r}398 \\
5.8\end{array}$ & $\begin{array}{c}399 . \\
8\end{array}$ & $\begin{array}{r}366 . \\
8\end{array}$ & $\mathrm{Ni}$ \\
\hline $\mathrm{Cu}$ & 1.4 & 0.1 & 33.2 & 18.2 & 13.5 & 47.9 & 25.4 & $\begin{array}{r}209 . \\
3\end{array}$ & $\mathrm{Cu}$ & $\begin{array}{r}428 . \\
6\end{array}$ & $\begin{array}{r}702 . \\
7\end{array}$ & $\begin{array}{c}450 . \\
1\end{array}$ & $\begin{array}{r}552 . \\
9\end{array}$ & 93.0 & 88.6 & $\mathrm{Cu}$ \\
\hline $\mathrm{Zn}$ & 7 & 1 & 386 & 43 & 14 & 14 & 8 & 5 & $\mathrm{Zn}$ & 9 & 124 & 11 & & 10 & 6 & $\mathrm{Zn}$ \\
\hline Ga & 0.04 & 0.5 & $<0.5$ & $<0.5$ & $<0.5$ & $<0.5$ & $<0.5$ & $<0.5$ & $\mathbf{G a}$ & $<0.5$ & $<0.5$ & 0.48 & $<0.5$ & 0.35 & $<0.5$ & Ga \\
\hline $\mathbf{R b}$ & 0.23 & 0.1 & 3.5 & 3.3 & 0.3 & 8.2 & 1.7 & 0.5 & $\mathbf{R b}$ & 1.5 & & 0.90 & $<0.1$ & 0.23 & $<0.1$ & $\mathbf{R b}$ \\
\hline $\mathrm{Sr}$ & 0.6 & 0.5 & 1.5 & 25.8 & 14.4 & 75.8 & 17.1 & 2.4 & $\mathrm{Sr}$ & 3 & 12.1 & 3.7 & 2.5 & 14.3 & 14.9 & $\mathrm{Sr}$ \\
\hline $\mathbf{Y}$ & 0.05 & 0.1 & 0.2 & 4.9 & 4 & 2.5 & 2.3 & 7.3 & & 5.2 & 2 & 8.31 & 3.5 & 1.92 & 1.7 & $\mathbf{Y}$ \\
\hline $\mathrm{Zr}$ & 6 & 0.1 & $\begin{array}{r}106 . \\
1\end{array}$ & 33.1 & 44.7 & 63.1 & 44.5 & 32.4 & & 66.4 & 3.9 & 6 & 22.4 & 6 & 2.3 & $\mathrm{Zr}$ \\
\hline $\mathrm{Nb}$ & 0.028 & 0.1 & 0.1 & $<0.1$ & $<0.1$ & $<0.1$ & $<0.1$ & $<0.1$ & $\mathrm{Nb}$ & $<0.1$ & 0.3 & $\begin{array}{c}0.03 \\
7\end{array}$ & $<0.1$ & $\begin{array}{c}0.05 \\
4\end{array}$ & $<0.1$ & $\mathrm{Nb}$ \\
\hline Mo & 0.08 & 0.1 & 1.5 & 2.2 & 0.5 & 2.1 & 0.6 & 6.3 & Mo & 0.6 & 0.3 & 0.16 & 0.6 & 0.79 & 0.4 & Mo \\
\hline $\mathrm{Cd}$ & 0.013 & 0.1 & 0.2 & $<0.1$ & $<0.1$ & $<0.1$ & $<0.1$ & $<0.1$ & $\mathrm{Cd}$ & $<0.1$ & 0.3 & $\begin{array}{c}0.03 \\
8\end{array}$ & $<0.1$ & $\begin{array}{c}0.03 \\
3\end{array}$ & $<0.1$ & $\mathrm{Cd}$ \\
\hline In & $\begin{array}{c}0.001 \\
8\end{array}$ & & & & & & & & In & & & $\begin{array}{c}0.00 \\
91\end{array}$ & & $\begin{array}{c}0.00 \\
40\end{array}$ & & In \\
\hline Sn & 0.16 & 1 & $<1$ & $<1$ & $<+$ & $<1$ & $<1$ & $<1$ & Sn & $<1$ & $<1$ & 0.16 & $<1$ & 0.16 & $<1$ & Sn \\
\hline Sb & 0.04 & 0.1 & 1.4 & 0.8 & 0.3 & 0.4 & 2.2 & $<0.1$ & $\mathrm{Sb}$ & 0.1 & $<0.1$ & 0.21 & 0.2 & 0.33 & 0.1 & $\mathrm{Sb}$ \\
\hline Cs & 0.013 & 0.1 & 0.2 & 1.5 & $<0.1$ & 2.2 & 0.9 & 0.3 & Cs & 0.5 & 0.2 & $\begin{array}{c}0.31 \\
6\end{array}$ & $<0.1$ & $\begin{array}{c}0.05 \\
5\end{array}$ & $<0.1$ & Cs \\
\hline $\mathrm{Ba}$ & 0.8 & & & 6 & 5 & 20 & 6 & 3 & $\mathrm{Ba}$ & 5 & 14 & 5.3 & 5 & 30.6 & 36 & $\mathrm{Ba}$ \\
\hline La & 0.04 & & 0.4 & 2.1 & 0.9 & 2 & 0.8 & 2.8 & La & 3.1 & 0.7 & 0.51 & 1.1 & 1.04 & 1.5 & La \\
\hline $\mathrm{Ce}$ & 0.12 & 0.1 & 0.5 & 3.4 & 1.4 & 3.3 & 1.1 & 4.3 & $\mathrm{Ce}$ & 4.8 & 1.6 & 1.25 & 1.2 & 1.62 & 1.7 & $\mathrm{Ce}$ \\
\hline
\end{tabular}

Table 2.

$\begin{array}{lllllllllllllllllllllllllllll}\mathbf{S} & \mathbf{H} & \mathbf{H} & \mathbf{H} & \mathbf{H} & \mathbf{H} & \mathbf{H} & \mathbf{S} & \mathbf{H} & \mathbf{H} & \mathbf{H} & \mathbf{H} & \mathbf{H} & \mathbf{H} & \mathbf{S} & \mathbf{H} & \mathbf{H} & \mathbf{H} & \mathbf{H} & \mathbf{H} & \mathbf{H} & \mathbf{S} & \mathbf{H} & \mathbf{H} & \mathbf{H} & \mathbf{H} & \mathbf{H} & \mathbf{H} \\ \mathbf{a} & 0 & 0 & 0 & 0 & 0 & 0 & \mathbf{a} & 0 & 0 & 1 & 1 & 1 & 1 & \mathbf{a} & 1 & 1 & 1 & 1 & 1 & 1 & \mathbf{a} & 1 & 1 & 1 & 1 & 1 & 1 \\ \mathbf{m} & 7 & 7 & 7 & 7 & 7 & 8 & \mathbf{m} & 8 & 8 & 1 & 1 & 1 & 1 & \mathbf{m} & 1 & 1 & 1 & 1 & 1 & 1 & \mathbf{m} & 1 & 1 & 1 & 1 & 1 & 1 \\ \mathbf{p} & - & - & - & - & - & - & \mathbf{p} & - & - & - & - & - & - & \mathbf{p} & - & - & - & - & - & - & \mathbf{p} & - & - & - & - & - & - \\ \mathbf{I} & 1 & 1 & 1 & 5 & 5 & 1 & \mathbf{I} & 8 & 8 & 0 & 0 & 0 & 0 & \mathbf{l} & 0 & 0 & 1 & 1 & 1 & 1 & \mathbf{I} & 1 & 1 & 1 & 1 & 1 & 1\end{array}$




$$
\begin{aligned}
& \text { e } \quad \begin{array}{llllllllllllllllllllllllllll}
0 & 0 & 0 & 6 & 6 & 0 & \text { e } & 0 & 0 & 5 & 5 & 8 & 8 & \text { e } & 8 & 8 & 3 & 3 & 3 & 3 & \text { e } & 3 & 6 & 3 & 6 & 6 & 6
\end{array}
\end{aligned}
$$

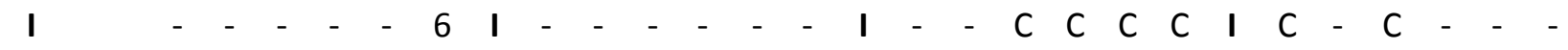

$$
\begin{aligned}
& \begin{array}{llllllllllllllllllllllllllllllllllllll}
\text { D } & 6 & 6 & 7 & 8 & 1 & 2 & - & \text { D } & 1 & 1 & 4 & 5 & 5 & 5 & \text { D } & 5 & 6 & - & - & - & - & \text { D } & - & 4 & - & 3 & 4 & 4
\end{array} \\
& \begin{array}{llllllllllllllllllllllll}
6 & 3 & 6 & 8 & 1 & 9 & 0 & 0 & 5 & 4 & 2 & 2 & 8 & 3 & 3 & 3 & 3 & 3 & 3 & 1 & 3 & 9 & 2 & 8
\end{array} \\
& \begin{array}{llllllllllllllllllllllll}
. & . & 8 & 0 & 8 & 3 & 7 & . & . & . & . & & 6 & 7 & 7 & 8 & 8 & 1 & 5 & 9 & 5 & 0
\end{array} \\
& \begin{array}{lllllllllllllllllllllll}
3 & 6 & 8 & . & . & . & & . & . & 5 & 2 & 6 & 6 & 3 & 9 & 3 & 6 & 8 & 7 & 9 & . & 7
\end{array} .
\end{aligned}
$$

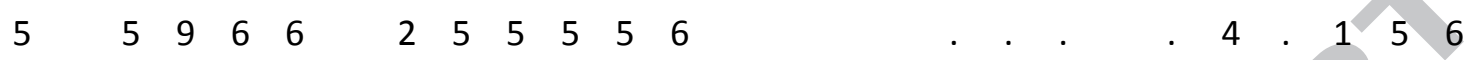

$$
\begin{aligned}
& \begin{array}{lllll}
5 & 7 & 2 & 4 & 1
\end{array}
\end{aligned}
$$

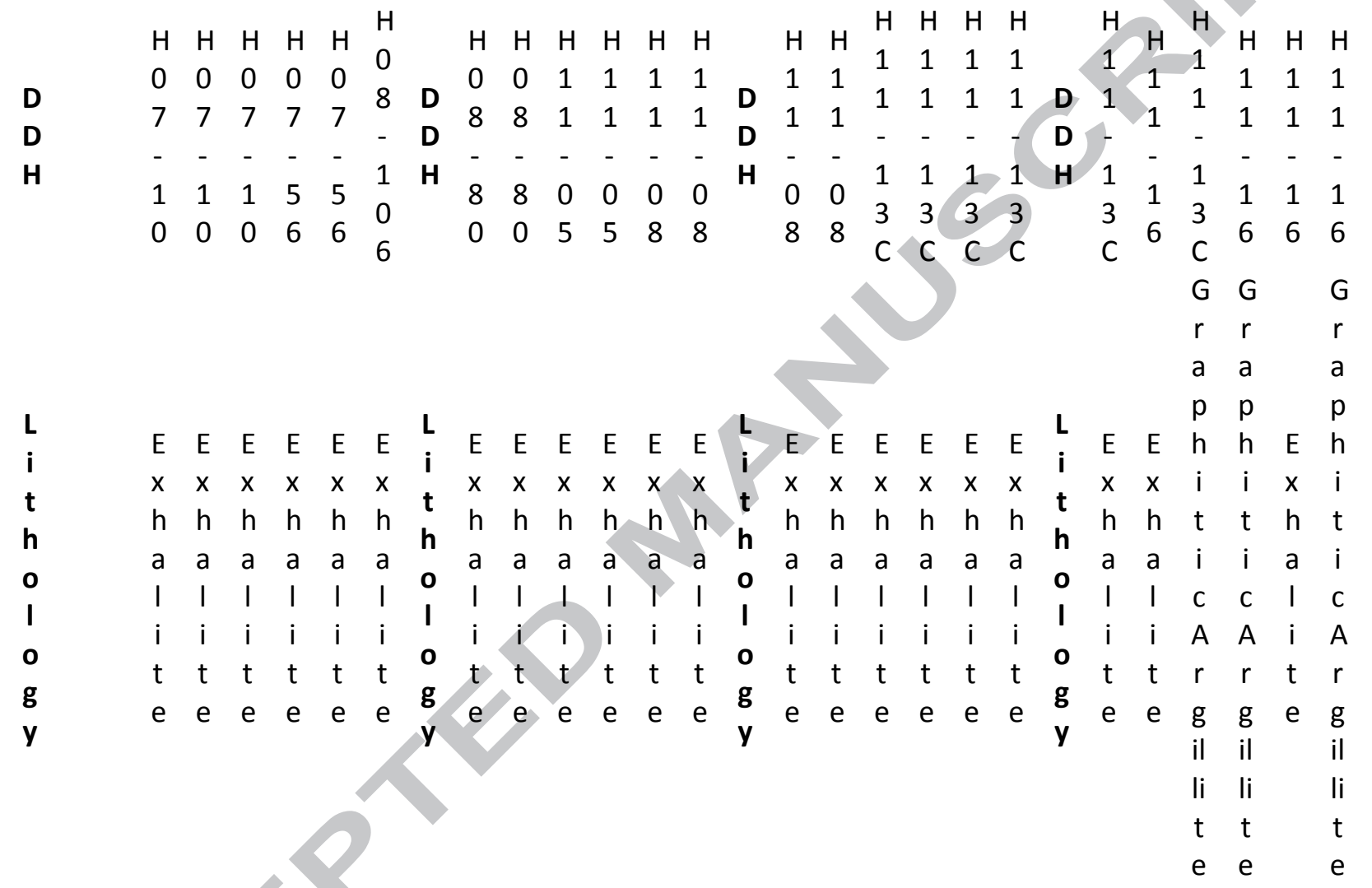

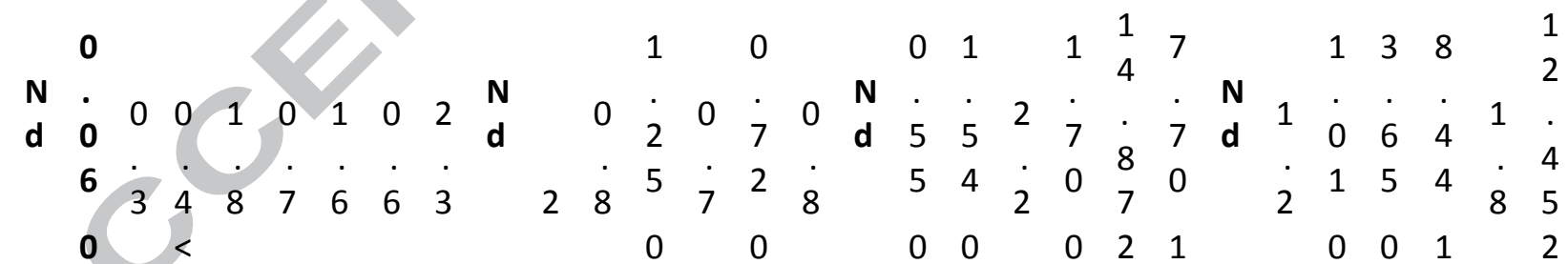
$\begin{array}{llllllllllllllllllllllllllllllll}\mathbf{S} & . & 0 & 0 & 0 & 0 & 0 & 0 & 0 & \mathbf{S} & 0 & 0 & . & 0 & . & 0 & \mathbf{S} & . & . & 0 & . & . & . & \mathbf{S} & 0 & . & . & . & 0 & . \\ \mathbf{m} & \mathbf{0} & . & . & . & . & . & . & . & . & \mathbf{m} & . & . & 3 & . & 1 & . & \mathbf{m} & 1 & 2 & . & 3 & 5 & 4 & \mathbf{m} & . & 1 & 7 & 7 & . & 7\end{array}$

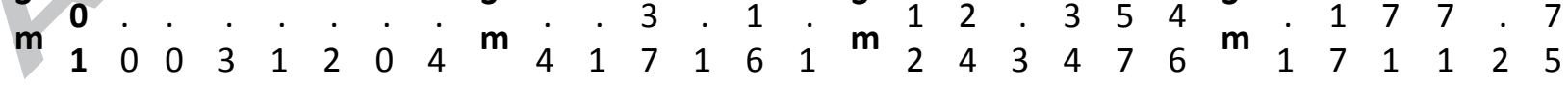

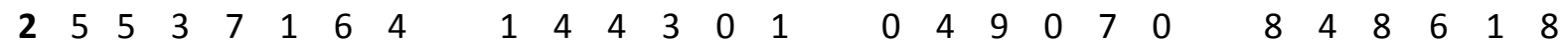
$\begin{array}{lllllllllllll}0 & 0 & 0 & 0 & 0 & 0 & 1 & 0 & 0 & 0 & 0 & 0\end{array}$

E $\begin{array}{lllllllllllllllllllllllllllll}\mathbf{0} & 0 & 0 & 0 & 0 & 0 & 0 & \mathrm{E} & 0 & 0 & 1 & 0 & 1 & 0 & \mathrm{E} & 0 & 2 & 0 & 3 & \dot{7} & \dot{6} & \mathrm{E} & 0 & 0 & \mathbf{2} & 8 & 0 & 7\end{array}$

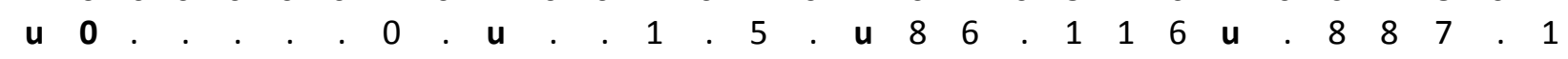
$\begin{array}{llllllllllllllllllllllllllll}3 & 0 & 0 & 2 & 1 & 0 & . & 3 & & 3 & 0 & 5 & 0 & 7 & 1 & 9 & 3 & 4 & 4 & 4 & 3 & 2 & 8 & 9 & 9 & 2 & 9\end{array}$

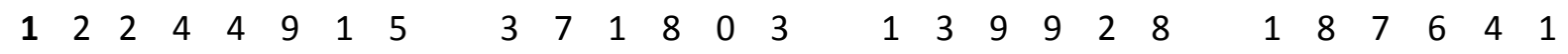




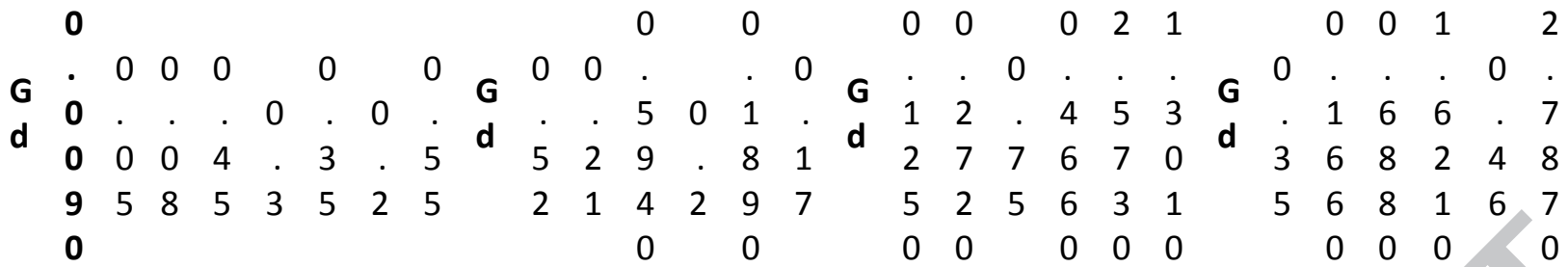
$\begin{array}{lllllllllllllllllllllllllllllll}\mathbf{T} & \mathbf{0} & 0 & 0 & 0 & 0 & 0 & 0 & 0 & \mathbf{T} & 0 & 0 & 1 & 0 & 0 & 0 & \mathbf{T} & 0 & 0 & 0 & 0 & \dot{0} & 1 & \mathbf{T} & 0 & 0 & 1 & 2 & 0 & 4\end{array}$

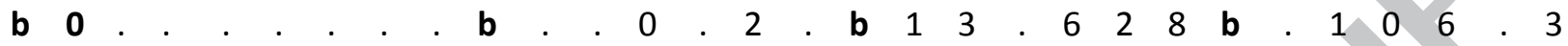

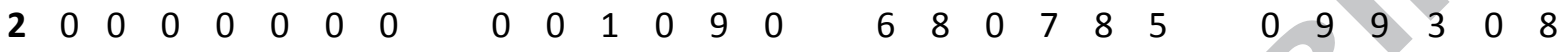
$\begin{array}{llllllllllllllllllllllllll}3 & 1 & 1 & 5 & 3 & 6 & 1 & 8 & 7 & 2 & 6 & 2 & 7 & 2 & 2 & 1 & 9 & 7 & 7 & 7 & 6 & 2 & 2 & 1 & 6 & 9\end{array}$ $\begin{array}{llllllllllllllll}0 & 0 & 0 & 0 & 0 & 0 & 2 & 1 & 0 & 0 & 1 & 2\end{array}$

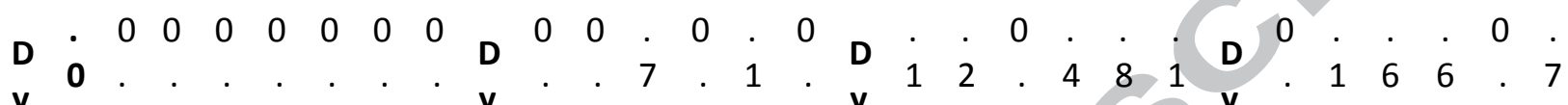
$\begin{array}{lllllllllllllllllllllllllllllll}\mathbf{y} & \mathbf{0} & . & . & . & . & . & . & . & \mathbf{y} & . & . & 7 & . & 1 & . & \mathbf{y} & 1 & 2 & . & 4 & 8 & 1 & \mathbf{y} & . & 1 & 6 & 6 & . & 7 \\ & \mathbf{0} & 0 & 0 & 4 & 2 & 3 & 2 & 6 & & 4 & 1 & 1 & 2 & 9 & 1 & \mathbf{y} & 1 & 7 & 7 & 8 & 8 & 8 & \mathbf{3} & 3 & 1 & 7 & 7 & 4 & 3\end{array}$ $\begin{array}{llllllllllllllllllllllllll}9 & 5 & 7 & 2 & 9 & 3 & 2 & 8 & 2 & 9 & 9 & 4 & 0 & 8 & 9 & 9 & 5 & 1 & 6 & 9 & 8 & 3 & 0 & 7 & 1 & 3\end{array}$ $\begin{array}{llllllllllll}0 & 0 & 0 & 0 & 0 & 0 & 0 & 0 & 0 & 0 & 0 & 0\end{array}$

$\begin{array}{llllllllllllllllllllllllllllll}\mathbf{H} & \mathbf{0} & 0 & 0 & 0 & 0 & 0 & 0 & 0 & \mathbf{H} & 0 & 1 & 0 & 0 & 0 & \mathbf{H} & 0 & 0 & 0 & 1 & 5 & 2 & \mathbf{H} & 0 & 0 & 1 & 3 & 0 & 5\end{array}$

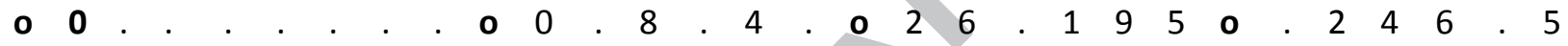
$\begin{array}{llllllllllllllllllllllllllll}2 & 0 & 0 & 0 & 0 & 0 & 0 & 1 & & 0 & 1 & 0 & 4 & 0 & 7 & 2 & 1 & 2 & 3 & 0 & & 1 & 7 & 0 & 5 & 1 & 6\end{array}$ $\begin{array}{lllllllllllllllllllllllllll}5 & 2 & 2 & 9 & 8 & 7 & 4 & 5 & 1 & 5 & 6 & 5 & 7 & 3 & 0 & 9 & 8 & 5 & 9 & 0 & & 1 & 8 & 1 & 9 & 1 & 5\end{array}$ $\begin{array}{lllllllllllll}0 & 0 & 0 & 0 & 0 & 0 & 1 & 0 & 0 & 0 & 1 & 1\end{array}$ $\begin{array}{lllllllllllllllllllllllllllllllll}\mathbf{E} & . & 0 & 0 & 0 & 0 & 0 & 0 & 0 & \mathbf{E} & 0 & 0 & . & & & 0 & \mathbf{E} & . & . & & . & . & . & \mathbf{E} & 0 & . & . & . & 0 & . \\ \mathbf{r} & \mathbf{0} & . & . & . & . & . & . & . & \mathbf{r} & . & . & 5 & 0 & 1 & . & \mathbf{r} & 0 & 2 & 0 & 3 & 7 & 7 & \mathbf{r} & . & 0 & 4 & 0 & . & 6\end{array}$

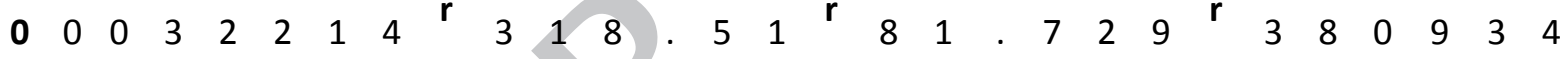
$\begin{array}{lllllllllllllllllllllllllll}7 & 3 & 4 & 9 & 6 & 1 & 4 & 7 & 7 & 7 & 7 & 2 & 0 & 2 & 3 & 3 & 6 & 7 & 1 & 4 & 9 & 3 & 1 & 2 & 8 & 9\end{array}$ $0 \quad \begin{array}{lllllllllll}0 & 0 & 0 & 0 & 0 & 0 & 0 & 0 & 0 & 0\end{array}$ $\begin{array}{lllllllllllllllllllllllllllllll}\mathbf{T} & \mathbf{0} & 0 & 0 & 0 & 0 & 0 & 0 & 0 & \mathbf{T} & 0 & 0 & 0 & 0 & 0 & 0 & \mathbf{T} & 0 & 0 & 0 & 0 & 2 & 1 & \mathbf{T} & 0 & 0 & 0 & 0 & 1 & 0 & 2\end{array}$

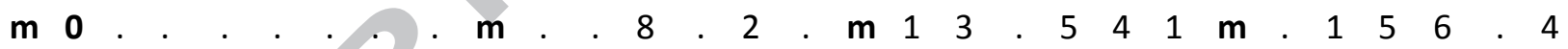
$\begin{array}{lllllllllllllllllllllllllll}1 & 0 & 0 & 0 & 0 & 0 & 0 & 0 & 0 & 0 & 7 & 0 & 2 & 0 & & 5 & 1 & 0 & 4 & 2 & 5 & 0 & 3 & 8 & 0 & 0 & 2\end{array}$

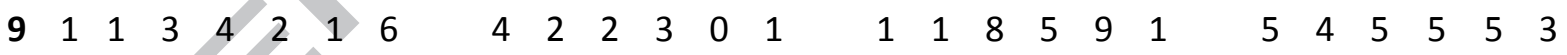
$\begin{array}{llllllllllllll}0 & 0 & 0 & 0 & 0 & 0 & 1 & 0 & 0 & 0 & 1 & 1\end{array}$ $\begin{array}{llllllllllllllllllllllllllllllll}\mathbf{Y} & \mathbf{.} & 0 & 0 & & 0 & 0 & 0 & 0 & \mathbf{y} & 0 & 0 & . & & . & 0 & \mathbf{r} & . & . & 0 & . & . & . & \mathbf{y} & 0 & . & . & . & 0 & . \\ \mathbf{b} & \mathbf{0} & . & & 0 & . & . & . & . & . & \mathbf{b} & . & . & 5 & 0 & 1 & . & \mathbf{b} & 0 & 1 & . & 3 & 5 & 7 & \mathbf{b} & . & 0 & 3 & 0 & . & 6\end{array}$

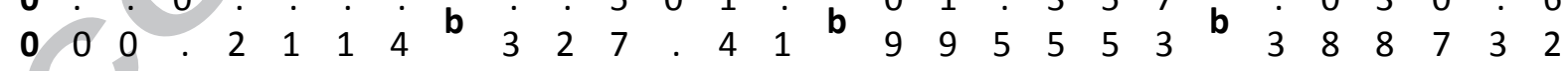
$\begin{array}{lllllllllllllllllllllllllll}9 & 5 & 5 & 3 & 4 & 2 & 1 & 6 & 4 & 5 & 5 & 2 & 0 & 3 & 2 & 8 & 9 & 5 & 3 & 8 & & 2 & 5 & 2 & 2 & 1 & 8\end{array}$ $0 \quad \begin{array}{lllllllllllll}0 & 0 & 0 & 0 & 0 & 0 & 0 & 0 & 0 & 0 & 0\end{array}$

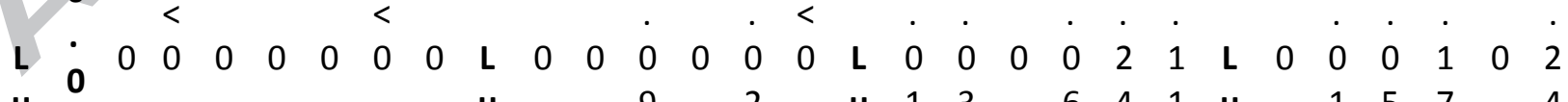
$\begin{array}{lllllllllllllllllllllllllllllll}\mathbf{u} & \mathbf{0} & 0 & . & . & . & . & . & . & . & \mathbf{u} & . & . & 9 & . & 2 & . & \mathbf{u} & 1 & 3 & . & 6 & 4 & 1 & \mathbf{u} & . & 1 & 5 & 7 & . & 4\end{array}$ $\begin{array}{lllllllllllllllllllllllllll}2 & 0 & 0 & 0 & 0 & 0 & 0 & 0 & 0 & 0 & 3 & 0 & 4 & 0 & 5 & 5 & 0 & 0 & 3 & 9 & 0 & 6 & 3 & 1 & 0 & 7\end{array}$ $\begin{array}{lllllllllllllllllllllllll}1 & 1 & 3 & 3 & 2 & 1 & 7 & 4 & 2 & 1 & 3 & 7 & 1 & 2 & 2 & 8 & 4 & 7 & 6 & 6 & 1 & 7 & 3 & 5 & 4\end{array}$ $0<<<<<<<31 \quad<\quad<\quad<1 \quad 2$ $\begin{array}{llllllllllllllllllllllllllllll}\mathbf{H} & . & 0 & 2 & 0 & 0 & 1 & & 0 & \mathbf{H} & 1 & 0 & 0 & 0 & 0 & 0 & \mathbf{H} & 0 & 0 & 0 & 0 & . & . & \mathbf{H} & 0 & 0 & . & . & 0\end{array}$.

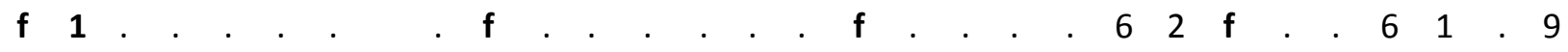

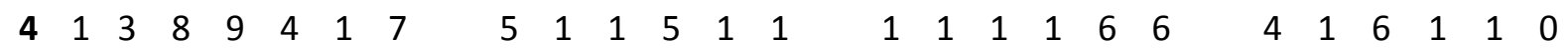




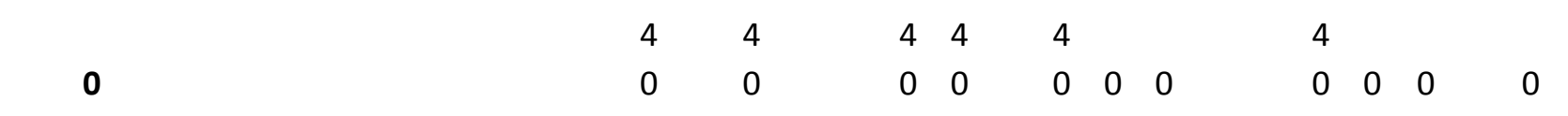

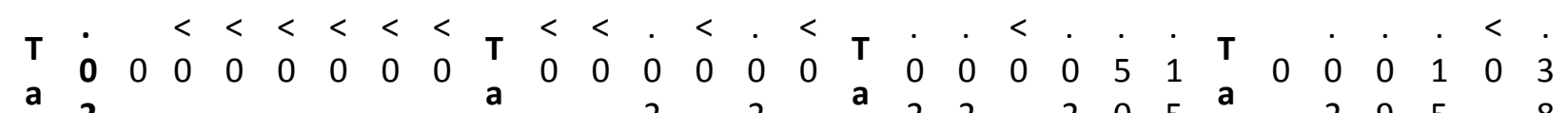

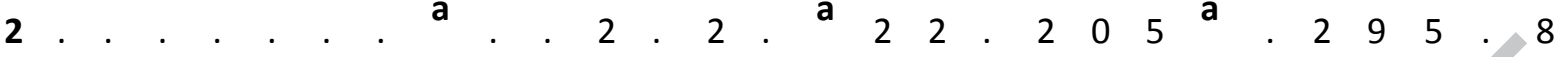

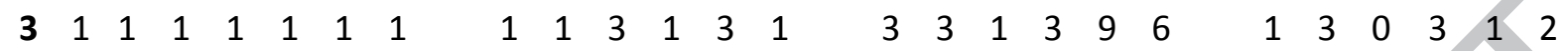

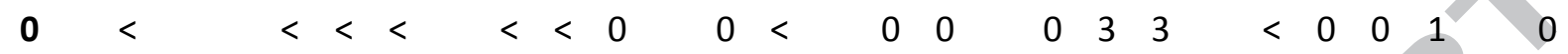
$\begin{array}{lllllllllllllllllllllllllllllllllllll}\mathbf{w} & . & 0 & 0 & 0 & 0 & 0 & 0 & 0 & \mathbf{w} & 0 & 0 & . & 0 & . & 0 & \mathbf{w} & . & . & 1 & . & . & . & \mathbf{w} & 0 & . & . & 0 & . \\ \mathbf{0} & . & . & . & . & . & . & . & & . & . & 0 & . & 0 & . & & 1 & 3 & . & 1 & 0 & 0 & & . & 1 & 5 & 7 & . & 6\end{array}$ $\begin{array}{lllllllllllllllllllllllllllll}5 & 5 & 5 & 5 & 5 & 5 & 5 & 5 & 5 & 5 & 6 & 7 & 7 & 5 & 2 & 0 & 9 & 8 & 5 & 0 & 5 & 4 & 5 & 7 & 7 & 3\end{array}$ $\begin{array}{lllllllllllllll}0 & 0 & 0 & 0 & 0 & 0 & 5 & 0 & 0 & 7 & 3 & 1\end{array}$

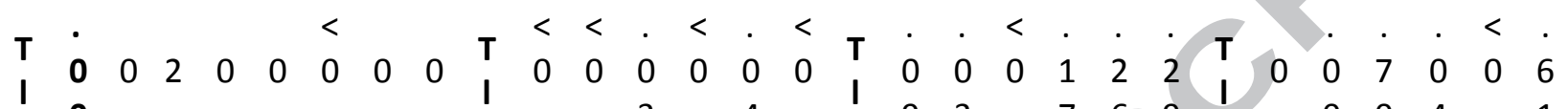

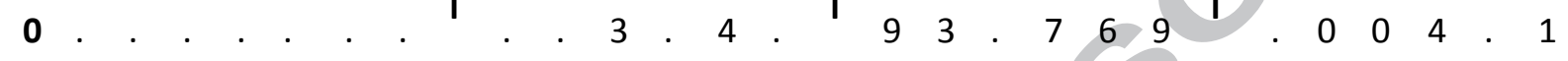

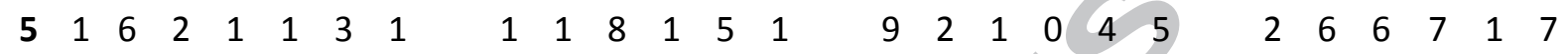
$\begin{array}{llllllllllllllllllllllllllllllllllllll}\mathbf{P} & 0 & 0 & 7 & 3 & 1 & 0 & 3 & 4 & \mathbf{P} & 3 & 4 & 6 & 7 & 4 & 3 & \mathbf{P} & 4 & 4 & 0 & 5 & 0 & 1 & \mathbf{P} & & 0 & 8 & 7 & 2 & 6\end{array}$

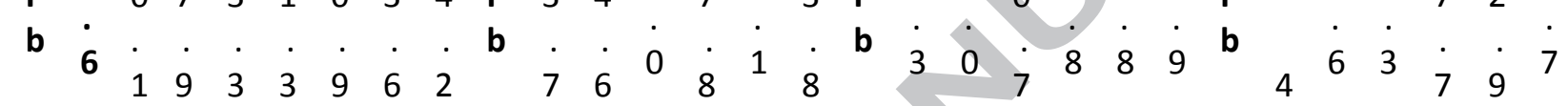

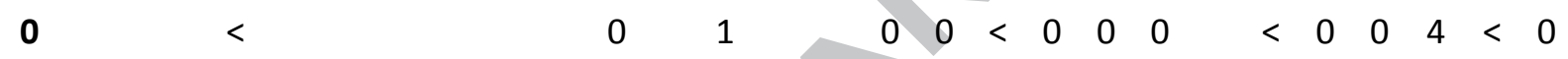

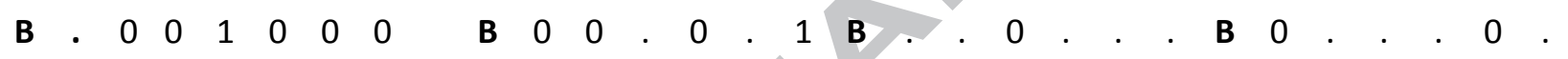

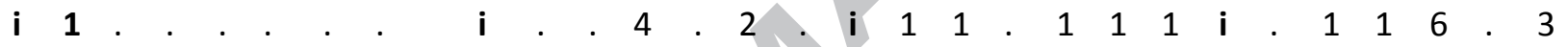

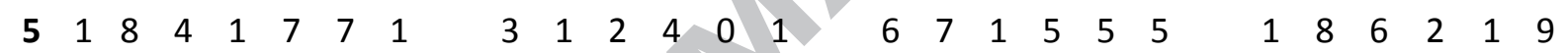
$\begin{array}{lllllllllllllll}0 & 0 & 0 & 0 & 0 & 0 & 2 & 1 & 0 & 0 & 1 & 2\end{array}$ $\begin{array}{llllllllllllllllllllllllllllll}\mathbf{T} & . & & < & < & < & < & < & < & \mathbf{T} & < & < & \dot{0} & < & \cdot & < & \mathbf{T} & . & . & < & . & . & . & \mathbf{T} & < & . & . & . & < & . \\ \mathbf{h} & \mathbf{0} & 0 & 0 & 0 & 0 & 0 & 0 & 0 & \mathbf{h} & 0 & 0 & 0 & 0 & 0 & 0 & \mathbf{h} & 0 & 0 & 0 & 0 & 5 & 0 & \mathbf{h} & 0 & 0 & 6 & 3 & 0 & 0\end{array}$

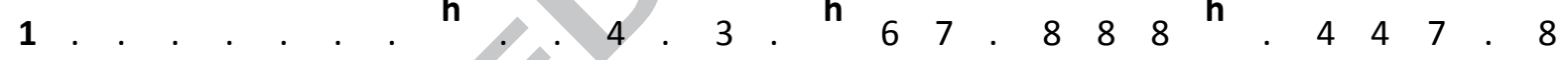
$\begin{array}{llllllllllllllllllllllllllll}8 & 2 & 2 & 2 & 2 & 2 & 2 & 2 & 2 & 2 & 9 & 2 & 2 & 2 & 3 & 3 & 2 & 3 & 1 & 8 & 2 & 4 & 7 & 8 & 2 & 3\end{array}$ $0 \quad \begin{array}{llllllllllll}0 & 0 & 0 & 0 & 0 & 0 & 0 & 0 & 0 & 0 & 0\end{array}$

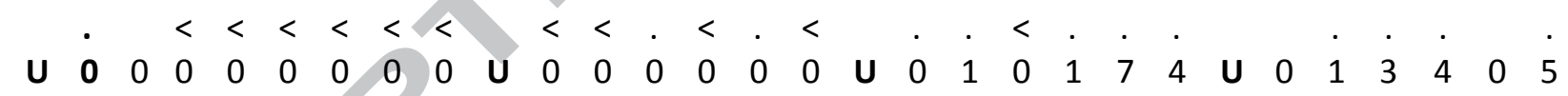

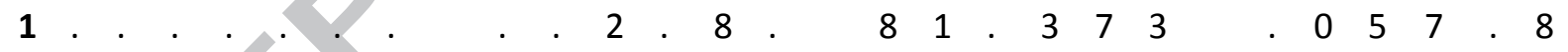
$\begin{array}{lllllllllllllllllllllllllll}1 & 1 & 1 & 1 & 1 & 1 & 1 & 1 & 1 & 1 & 5 & 1 & 5 & 1 & 4 & 1 & 1 & 3 & 1 & 0 & & 1 & 1 & 8 & 4 & 2 & 9\end{array}$ 


\begin{tabular}{|c|c|c|c|c|c|c|}
\hline Sample ID & DDH/Trench & Lithology/Comment & $\begin{array}{l}\delta^{33} S_{V-C D T} \\
\pm 0.3(2 \sigma)\end{array}$ & $\begin{array}{l}\delta^{34} S_{\mathrm{V}-\mathrm{CDT}} \\
\pm 0.3(2 \sigma)\end{array}$ & $\begin{array}{c}\Delta^{33} S \\
\pm 0.02(2 \sigma)\end{array}$ & $\begin{array}{c}\delta^{56 / 54} \mathrm{Fe}_{\mathrm{IRMM}-14} \\
\pm 0.06(2 \sigma)\end{array}$ \\
\hline H07-10-66.35 & H07-10 & Exhalite & 0.1 & 3.0 & -1.37 & -2.04 \\
\hline H07-10-73.6 & $\mathrm{H} 07-10$ & Exhalite & -3.4 & -5.6 & -0.55 & -1.80 \\
\hline H07-10-86.85 & H07-10 & Exhalite & -3.1 & -4.9 & -0.54 & -1.91 \\
\hline H07-56-188.9 & H07-56 & Exhalite & -0.6 & 0.7 & -0.95 & -1.63 \\
\hline H07-56-210.6 & H07-56 & Exhalite & 0.5 & 2.4 & -0.70 & -2.13 \\
\hline H08-106-98.6 & H08-106 & Exhalite & 0.6 & 2.4 & -0.69 & \\
\hline H08-80-103.2 & $\mathrm{H} 08-80$ & Exhalite & -2.5 & -4.1 & -0.42 & -1.60 \\
\hline H08-80-107.5 & $\mathrm{H} 08-80$ & Exhalite & -4.4 & -7.6 & -0.54 & -1.60 \\
\hline H11-05-45.55 & $\mathrm{H} 11-05$ & Exhalite & -5.2 & -9.0 & -0.58 & -1.22 \\
\hline H11-05-54.25 & $\mathrm{H} 11-05$ & Exhalite & 2.1 & 5.5 & -0.74 & -1.40 \\
\hline H11-08-52.65 & H11-08 & Exhalite & -6.3 & -11.4 & -0.46 & -2.04 \\
\hline H11-08-58.3 & H11-08 & Exhalite & -5.3 & -9.3 & -0.45 & -1.75 \\
\hline H11-08-63.9 & $\mathrm{H} 11-08$ & Exhalite & 3.2 & 7.6 & -0.66 & \\
\hline H11-13C-363 & $\mathrm{H} 11-13 \mathrm{C}$ & Exhalite & 0.6 & 2.1 & -0.46 & -1.36 \\
\hline $\begin{array}{c}\text { H11-13C- } \\
376.5\end{array}$ & $\mathrm{H} 11-13 \mathrm{C}$ & Exhalite & -3.4 & -5.2 & -0.75 & -1.90 \\
\hline $\begin{array}{c}\text { H11-13C- } \\
378.7\end{array}$ & $\mathrm{H} 11-13 \mathrm{C}$ & Exhalite & 0.6 & 2.6 & -0.79 & -1.73 \\
\hline $\begin{array}{c}\mathrm{H} 11-13 \mathrm{C}- \\
387.2\end{array}$ & $\mathrm{H} 11-13 \mathrm{C}$ & Exhalite & -0.5 & -0.3 & -0.34 & -1.96 \\
\hline $\begin{array}{c}\mathrm{H} 11-13 \mathrm{C}- \\
389.45\end{array}$ & $\mathrm{H} 11-13 \mathrm{C}$ & Exhalite & -0.4 & 0.2 & -0.43 & -2.08 \\
\hline H11-16-411.4 & H11-16 & Exhalite & -0.1 & 0.7 & -0.44 & -0.85 \\
\hline H11-16-425.5 & H11-16 & Exhalite & -1.4 & -1.7 & -0.49 & -1.45 \\
\hline MGH502 & MGH502 & Exhalite & -6.2 & -11.0 & -0.53 & \\
\hline MGH600A & MGH600 & Exhalite & -2.1 & -2.8 & -0.66 & \\
\hline MGH600B & MGH600 & Exhalite & 2.1 & 5.5 & -0.73 & \\
\hline MGH601B & MGH601 & Exhalite & -5.8 & -10.0 & -0.61 & \\
\hline $\begin{array}{c}\mathrm{H} 11-13 \mathrm{C}- \\
357.1\end{array}$ & $\mathrm{H} 11-13 \mathrm{C}$ & Graphitic Argillite & 0.9 & 3.5 & -0.94 & -1.86 \\
\hline H11-16-399.1 & $\mathrm{H} 11-16$ & Graphitic Argillite & 0.6 & 1.6 & -0.19 & -1.96 \\
\hline$H 11-16-480.6$ & $\mathrm{H} 11-16$ & Graphitic Argillite & 2.3 & 5.0 & -0.28 & -1.66 \\
\hline
\end{tabular}


Table 3.

$\mathrm{H} 11$ H11 H11 H11 H11- H11- H11- H11 H07 H07 H07 H07 $\mathrm{H07}$

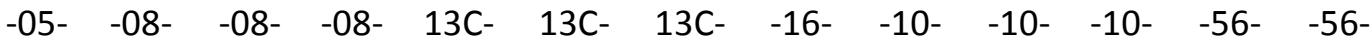

$\begin{array}{lllllllllllll}45.5 & 52.6 & 58 . & 63 . & 376 . & 378 . & 387 . & 411 . & 66.3 & 73 . & 86.8 & 188 . & 210 .\end{array}$

Formu

$\begin{array}{lllllllllllll}5 & 6 & 3 & 9 & 5 & 7 & 2 & 4 & 5 & 6 & 5 & 9 & 6\end{array}$

la

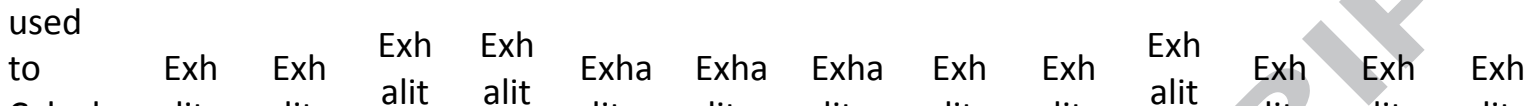

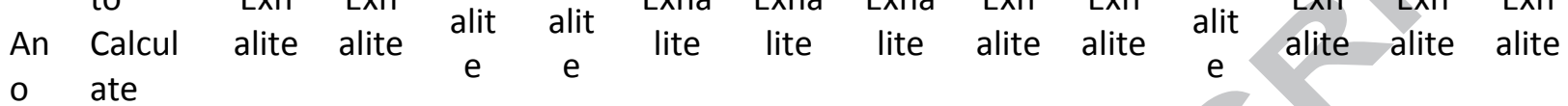

m Anom

aly aly

$\mathrm{La} /(3 \mathrm{P}$

$\begin{array}{llllllllllllll}r- & 5.56 & 1.27 & 2.4 & 1.6 & 1.56 & 0.98 & 1.07 & 1.36 & 0.61 & 1.0 & 0.88 & 1.67 & 1.10\end{array}$

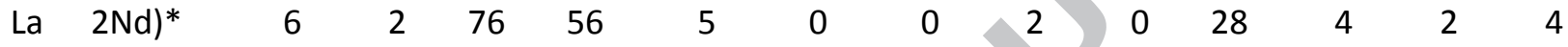

$\mathrm{Ce} /(2 \mathrm{P}$

$r-$

$\begin{array}{lllllllllllll}1.46 & 0.95 & 1.2 & 1.0 & 1.05 & 0.91 & 0.95 & 1.02 & 0.40 & 0.8 & 0.71 & 1.13 & 0.74\end{array}$

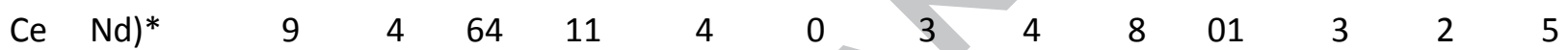

$\operatorname{Pr} /(1 /$

$2 \mathrm{Ce}+$

$\begin{array}{llllllllllllll}1 / 2 \mathrm{Nd} & 0.90 & 1.02 & 0.9 & 0.9 & 0.97 & 1.05 & 1.02 & 0.98 & 1.50 & 1.1 & 1.18 & 0.94 & 1.15\end{array}$

$\begin{array}{llllllllllllll}\operatorname{Pr} \quad * & 5 & 4 & 13 & 94 & 6 & 0 & 3 & 9 & 3 & 11 & 5 & 5 & 0\end{array}$

$\mathrm{Eu} /(2 /$

$3 \mathrm{Sm}+$

$\begin{array}{lllllllllllll}1 / 3 \mathrm{~Tb}) & 1.20 & 4.54 & 3.8 & 5.3 & 4.17 & 3.21 & 2.40 & 2.81 & 3.6 & 3.89 & 1.63 & 8.04\end{array}$

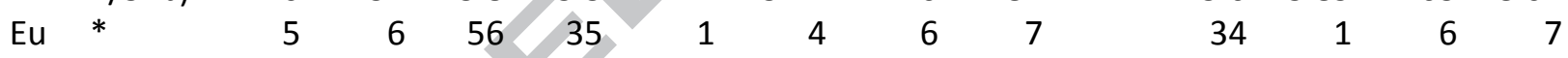

$\begin{array}{llllllllllllll}\mathrm{Gd} /(2 \mathrm{~T} & & & & & & & & & & & & & \\ \mathrm{b}- & 1.17 & 1.12 & 1.6 & 1.5 & 1.38 & 1.12 & 1.23 & 1.39 & 2.4 & 4.13 & 0.88 & 2.02\end{array}$

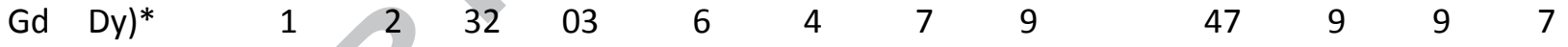

$\begin{array}{llllllllllllll}\text { Y/ } & 45.7 & 42.9 & 40 & 58 . & 42.9 & 32.5 & 33.7 & 43.8 & 54 . & 50.0 & 35.7 & 57.5\end{array}$

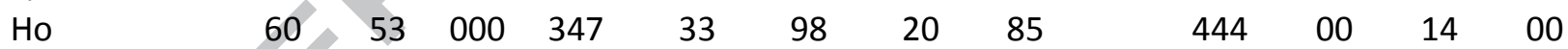

$\mathrm{Gd}$

$/ Y$

$\begin{array}{lllllllllllll}0.62 & 0.81 & 0.8 & 0.8 & 0.79 & 1.00 & 1.06 & 1.18 & 0.96 & 0.9 & 0.75 & 1.76 & 1.10\end{array}$

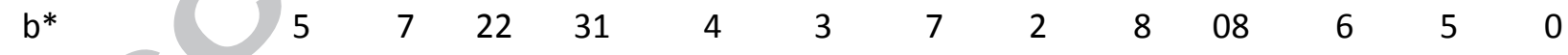

$\begin{array}{llllllllllllll}\mathrm{Pr} & & & & & & & & & \\ \mathrm{Y} & 0.11 & 0.42 & 0.3 & 0.6 & 0.36 & 0.83 & 0.84 & 0.95 & 0.76 & 0.5 & 0.26 & 0.98 & 0.46\end{array}$

$\begin{array}{llllllllllllll}\mathrm{b}^{*} & 7 & 9 & 89 & 68 & 4 & 8 & 9 & 4 & 6 & 00 & 6 & 5 & 5\end{array}$

*Calculated using

PAAS-normalized

values 